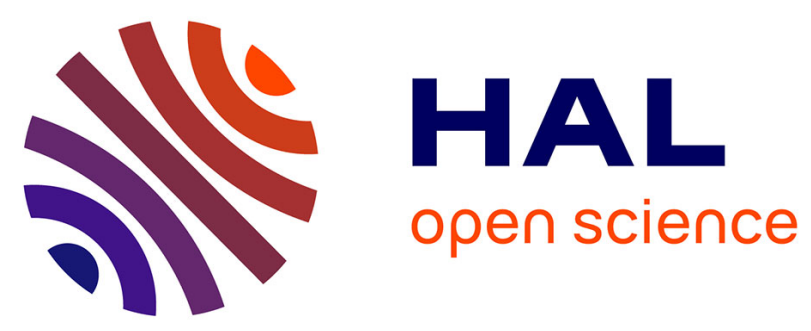

\title{
The moroccan Anti-Atlas ophiolites: Timing and melting processes in an intra-oceanic arc-back-arc environment
}

Florent Hodel, Antoine Triantafyllou, Julien Berger, Mélina Macouin, Jean-Marc Baele, Nadine Mattielli, Christophe Monnier, R. Ivan Ferreira da Trindade, M.N. Ducea, Adil Chatir, et al.

\section{To cite this version:}

Florent Hodel, Antoine Triantafyllou, Julien Berger, Mélina Macouin, Jean-Marc Baele, et al.. The moroccan Anti-Atlas ophiolites: Timing and melting processes in an intra-oceanic arc-back-arc environment. Gondwana Research, 2020, 86 (182-202), 10.1016/j.gr.2020.05.014 . insu-02886228

\section{HAL Id: insu-02886228 \\ https://hal-insu.archives-ouvertes.fr/insu-02886228}

Submitted on 2 Jul 2020

HAL is a multi-disciplinary open access archive for the deposit and dissemination of scientific research documents, whether they are published or not. The documents may come from teaching and research institutions in France or abroad, or from public or private research centers.
L'archive ouverte pluridisciplinaire HAL, est destinée au dépôt et à la diffusion de documents scientifiques de niveau recherche, publiés ou non, émanant des établissements d'enseignement et de recherche français ou étrangers, des laboratoires publics ou privés. 


\section{Journal Pre-proof}

The Moroccan Anti-Atlas ophiolites: Timing and melting processes in an intra-oceanic arc-back-arc environment

F. Hodel, A. Triantafyllou, J. Berger, M. Macouin, J.-M. Baele, N. Mattielli, C. Monnier, R.I.F. Trindade, M.N. Ducea, A. Chatir, N. Ennih, J. Langlade, M. Poujol

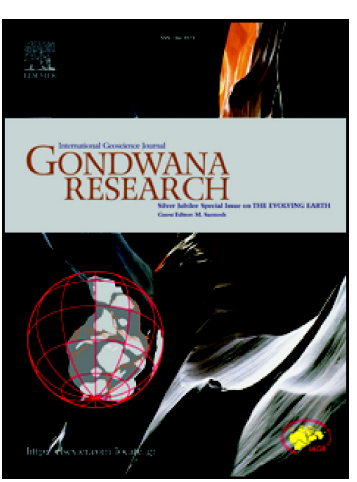

PII:

S1342-937X(20)30178-7

DOI: https://doi.org/10.1016/j.gr.2020.05.014

Reference:

GR 2363

To appear in:

Gondwana Research

Received date:

31 January 2020

Revised date:

22 May 2020

Accepted date:

23 May 2020

Please cite this article as: F. Hodel, A. Triantafyllou, J. Berger, et al., The Moroccan Anti-Atlas ophiolites: Timing and melting processes in an intra-oceanic arc-back-arc environment, Gondwana Research (2020), https://doi.org/10.1016/j.gr.2020.05.014

This is a PDF file of an article that has undergone enhancements after acceptance, such as the addition of a cover page and metadata, and formatting for readability, but it is not yet the definitive version of record. This version will undergo additional copyediting, typesetting and review before it is published in its final form, but we are providing this version to give early visibility of the article. Please note that, during the production process, errors may be discovered which could affect the content, and all legal disclaimers that apply to the journal pertain.

(C) 2020 Published by Elsevier. 


\section{The Moroccan Anti-Atlas ophiolites: Timing and melting processes in an intra-oceanic arc-back-arc environment}

F. Hodel ${ }^{1}$, A. Triantafyllou ${ }^{2,3}$, J. Berger ${ }^{1}$, M. Macouin ${ }^{1}$, J-M. Baele ${ }^{4}$, N. Mattielli ${ }^{5}$, C. Monnier ${ }^{6}$, R. I. F Trindade ${ }^{7}$, M. N. Ducea ${ }^{3,8}$, A. Chatir ${ }^{9}$, N. Ennih $^{9}$, J. Langlade $^{10}$, M. Poujol ${ }^{11}$

${ }^{1}$ Géosciences Environnement Toulouse (GET), Observatoire de Midi-Pyrénées, CNRS, IRD, Université Toulouse III Paul Sabatier, 14, Avenue Edouard Belin, 31400 Toulouse, France.

${ }^{2}$ Department of Geology, University of Liège, Sart Tilman, Liège, Belgium

${ }^{3}$ Department of Geosciences, University of Arizona, Tucson, Arizona 85721, USA

${ }^{4}$ Geology and Applied Geology unit - Mining Geology, Université de Mons, 20, Place du Parc, B-7000, Belgium.

${ }^{5}$ Department of Earth and Environmental Sciences - G-Time Laboratory, Université Libre de Bruxelles, 50 Avenue Franklin Roosevelt, 1050 Brussels, Belgium. ${ }^{6}$ Laboratoire de Planétologie et Géodynamique - Nantes (LPGN), UFR Sciences et Techniques, Université de Nantes, UMR-CNRS 6112, France.

${ }^{7}$ Instituto de Astronomia, Geofísica e Ciências Atmosféricas, Universitad de São Paulo, 05508-900 São Paulo, Brazil.

${ }^{8}$ Faculty of Geology and Geophysics, University of Bucharest, Bucharest, Romania

${ }^{9}$ EGGPG, Département de Géologie, Faculté des Sciences, Université Chouaïb Doukkali, 24000 El Jadida, Morocco

${ }^{10}$ Microsonde Ouest, Ifremer-Centre de Bretagne, Technopole Brest Iroise, BP70, F-29280, Plouzané, France

${ }^{11}$ Univ Rennes, CNRS, Géosciences Rennes, UMR 6118, 35000 Rennes, France 


\section{Abstract}

The Moroccan Anti-Atlas orogenic belt encloses several Precambrian inliers comprising two major Neoproterozoic ophiolitic complexes: the Sirwa and Bou Azzer ophiolites. These ophiolites expose crustal and mantle units, thrusting over fragments of a long-lived intraoceanic arc system. We present a detailed geochronological and petro-geochemical study of three mafic/ultramafic units of these two ophiolites: the Khzama sequence (Sirwa ophiolite) and the Northern and Southern Aï Ahmane sequences (Bou Azzer ophiolite). The crystallization of layered metagabbros from the Bou Azzer ophiolite (North Aït Ahmane sequence) has been dated here at $759 \pm 2 \mathrm{Ma}(\mathrm{U}-\mathrm{Pb}$ on zircons). This new age for the Bou Azzer ophiolite is similar to the formation of the Sirwa ophiolite (762 Ma) and suggests that both units formed during the same spreading event. Metabasalts of the three units show tholeiitic signature but with variable subduction-related imprints marked by LILE enrichments, HFSE depletions and variable Ti contents, similar to modern back-arc basin basalts (BABB). Their back-arc origin is also supported by the geochemical signature of ultramafic units showing very low contents in major and trace incompatible elements $\left(\mathrm{Al}_{2} \mathrm{O}_{3}\right.$ : 0.12-1.53 wt\%, Ti: $3.5-64.2 \mathrm{ppm}$ and $\mathrm{Nb}$ : 0.004-0.10 ppm), attesting of a highly refractory protolith. This is in agreement with the high $\mathrm{Cr} \#(0.44-0.81)$ and low to intermediate $\mathrm{Mg \#}$ (0.25-0.73) of their constitutive Cr-spinels. Dynamic melting models suggest that these serpentinites experienced intense and polyphased hydrous melting events, strongly influenced by supra-subduction zone SSZ-fluid influx and subduction-related melt percolation. Being particularly affected by these SSZ-melt/rock interactions and closer to arc units to the south, the Sirwa ophiolite and the South Aït Ahmane unit of the Bou Azzer ophiolite likely represent an early stage of the arc-back-arc system, which has been more influenced by the magmatic products of the arc activity compared to the North Ait Ahmane unit of the Bou Azzer ophiolite. 
Keywords: Neoproterozoic, SSZ, ophiolite, back-arc, U-Pb dating, serpentinite, West

African Craton.

\section{Introduction}

Due to lithosphere recycling induced by plate tectonics, no oceanic lithosphere older than 220 Ma remains in place nowadays (Müller et al., 2008). Ophiolites are therefore the only available objects to investigate older oceanic lithosphere. A recent census by Furnes et al. (2015) highlights a great abundance of Neoproterozoic and early Cambrian ophiolites worldwide, mostly dated from 850 Ma to $500 \mathrm{Ma}$, testifying of a peculiar geodynamic activity at that time, marked by the demise of the Rodinia supercontinent and the further assembly of Gondwana. Most of these ophiolites are interpreted as remnants of supra-subduction lithosphere (e.g. Dilek and Furnes, 2011; Stern et al., 2012). They expose in places complete vertical sections of supra-subduction lithosphere, poorly accessible on modern active systems. Back- or fore-arc basins remnants can provide key information about the tectonic regime of the overriding plate (Heuret and Lallemand, 2005) and therefore, new insights into subduction dynamics. Therefore, these Neoproterozoic ophiolites offer unique opportunities to study crustal production, subduction zones dynamics (Triantafyllou et al., 2016, 2018; Walsh et al., 2012) and oceanic hydrothermal activity (Hodel et al., 2017, 2018), associated to this critical period of the Earth's history (e.g. Stern, 2005).

Recent ocean drilling campaigns emphasized the geochemical heterogeneity of suprasubduction systems and the diversity of igneous processes depending on arc vicinity, slab dynamics, mantle enrichment and melting process (Hochstaeder et al., 2001; Tollstrup et al., 2010; Reagan et al., 2017). These new views on modern subduction systems reveal that deciphering a geodynamic context with geochemical discrimination tools applied to metabasaltic ophiolitic rocks can be difficult (see MacLeod et al., 2013 for the debate on the 
Oman ophiolite). Hence, by exposing both mafic and ultramafic lithologies of a given lithosphere section, ophiolites are prime targets to understand subduction systems and explain their geochemical diversity.

The Moroccan Anti-Atlas hosts several Neoproterozoic inliers (erosional windows) comprising ophiolitic sequences that offer a unique opportunity to study these particular subduction settings (Bousquet et al., 2008). In the present study, we focus on the two main ophiolitic sequences exposed in the Anti-Atlas: the Sirwa ophiolite (e.g., Chabane, 1991; El Boukhari et al., 1992; Admou and Juteau, 1998), dated at $762 \pm 2$ Ma by Samson et al. (2004), and the Bou Azzer ophiolite (e.g. Leblanc, 1975; Bodinier et al., 1984; Naidoo et al., 1991; Ahmed et al., 2005, 2009). The age of the Bou Azzer ophiolite is still debated (El Hadi et al., 2010), the most commonly quoted age being a $\mathrm{Rb} / \mathrm{Sr}$ age of $788 \pm 10 \mathrm{Ma}$ (Clauer, 1976), obtained on hornsfel pelites collected close to meter-thick mafic sills.

Only a few studies treat of the ultramafic lithologies of these ophiolitic sequences (Leblanc, 1975; Ahmed et al., 2005; Gahlan et al., 2006; Hodel et al., 2017, 2018) and their petrology along with their geochemistry remain poorly constrained. Here we present a detailed petrological study of the ultramafic and the mafic units coupled with a geochronological study of the constitutive mafic rocks of the Sirwa and Bou Azzer ophiolites in order to better constrain their age and origin.

\section{Geological context}

The Moroccan ophiolites are part of the Precambrian basement cropping out in the central Anti-Atlas mountain range (Gasquet et al., 2005). These Precambrian inliers are exposed between two major fault zones (the South Atlas Fault, SAF and the Anti-Atlas Major Fault, AAMF), testify to the intense tectonic history that affected the northern margin of the West African Craton (WAC; Fig. 1a) during the Pan-African orogeny. Ophiolitic assemblages are 
exposed in two inliers: the Sirwa window to the west (Fig. 1b) and the Bou Azzer-El Graara inlier to the East (Fig. 1b).

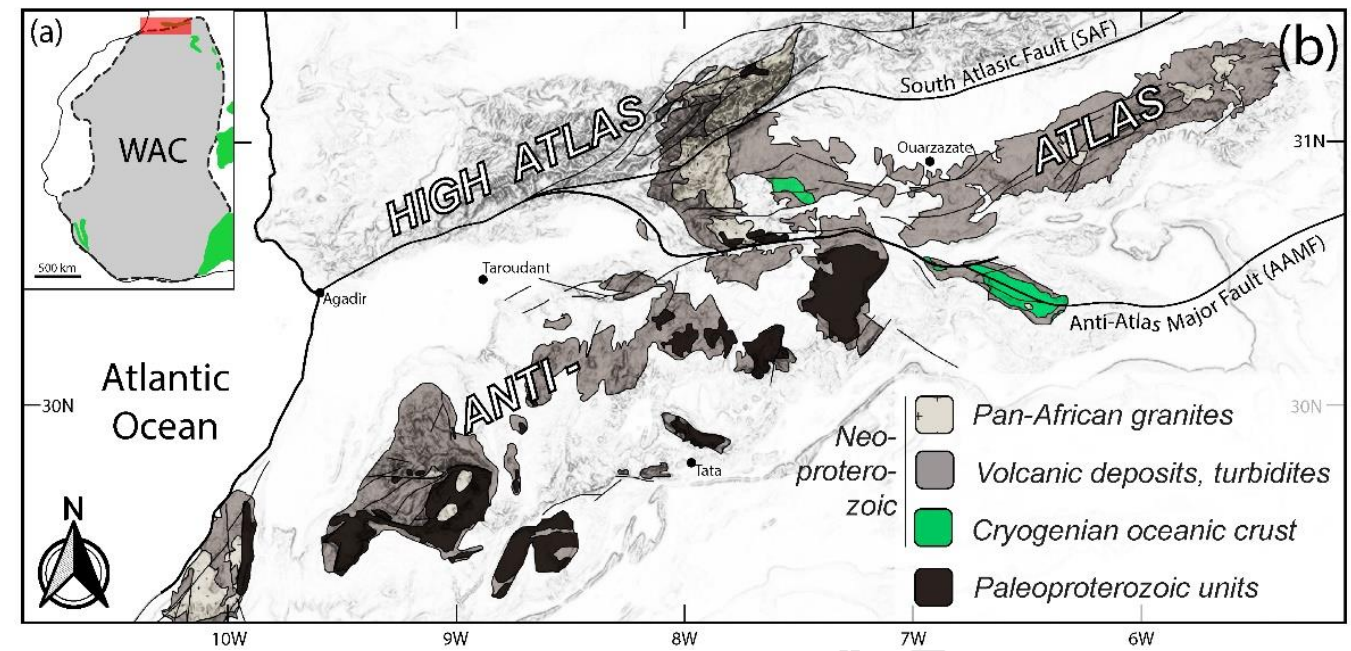

Figure 1: Simplified geological maps. (a) Location of the studied area in relation to the West African Craton (WAC). Green parts represent the Pan-African orogenic belt. (b) Schematic map of the Precambrian inliers exposed in the Moroccan AntiAtlas mountain belt (modified after Gasquet et al., 2008; basemap is Aster GDem 2.0 topographic data) showing the Sirwa and the Bou Azzer - El Graara inliers to the $W$ and the E, respectively.

Both inliers consist of several stacked tectonic blocks interpreted as dismembered parts of a Cryogenian (middle Neoproterozoic) oceanic supra-subduction system (e.g. Leblanc, 1975; Saquaque et al., 1989; Bodinier et al., 1984; Bousquet et al., 2008; Walsh et al., 2012; El Hadi et al., 2010; Soulaimani et al., 2018). These units were molded along the AAMF (Fig. 1b), surrounded and locally unconformably overlain by the Ediacaran (late Neoproterozoic) volcano-clastic deposits of the Ouarzazate Supergroup and late Ediacaran to Early Cambrian clastic sediments (Leblanc, 1981). Both inliers show strong field and petrological similarities that can be summarized as follows:

(1) Neoproterozoic intra-oceanic arc remnants. They consist of meta-volcanic and -plutonic units, heterogeneous in composition (mafic to felsic), which are affected by a polyphased intrusive and deformation history. 
In the Sirwa inlier, the Iriri-Tachakoucht-Tourtit arc complex is composed of andesitic to dacitic gneisses (Tachakoucht formation, Fig. 2a), intruded by hornblenditic magmas and hornblende gabbro dikes (mafic intrusions of Iriri, Fig. 2a). The contact between these intrusive bodies and the gneisses consists of leucocratic horizons, produced by the partial melting of the host gneiss. The orthogneiss of the Tachakoucht formation yields protolithic ages comprised between $735 \pm 7 \mathrm{Ma}$ and $725 \pm 7 \mathrm{Ma}$ (Thomas et al., 2002; Triantafyllou et al., 2016). The leucocratic horizons produced by their localized partial melting induced by the Iriri intrusions are younger, between $651 \pm 5 \mathrm{Ma}$ and $641 \pm 5 \mathrm{Ma}$ (see zircons' metamorphic overgrowths in, Thomas et al., 2002; Triantafyllou et al., 2016). The Iriri-Tachakoucht-Tourtit complex appears to be the product of several successive magmatic episodes with an intraoceanic arc geochemical signature (Thomas et al., 2002; Triantafyllou et al., 2016; 2020).

In the Bou Azzer inlier, these arc remnants form a discontinuous strip along the southern border of the inlier and are mainly exposed within the Bougmane (Fig. 2b, south of the ophiolitic sequences) and Tazigzaout complexes (outside the area covered by the map in Fig. 2b). These highly metamorphosed complexes are composed of mafic gneisses (amphibolite) as well as granitic orthogneiss and granodioritic augen gneisses (see Triantafyllou et al., 2018). Triantafyllou et al. $(2018,2020)$ show that the Bougmane complex consists of $760-740$ Ma heterogeneously mingled felsic-mafic orthogneiss intruded by several bodies of 710-690 Ma hornblendites, hornblende gabbros and garnet leucosomes. Garnet reaction zones form at the contact between different hornblende gabbro intrusions as a consequence of dehydration and dehydration melting under high pressure (garnet-present) granulite grade conditions $\left(\sim 800^{\circ} \mathrm{C}, 10 \mathrm{kbar}\right.$; Triantafyllou et al., 2018). These reactions induced by contact metamorphism are responsible for the formation of garnet-bearing leucosomes during incipient partial melting of hornblende-rich rocks. As well as for the Iriri-Tachakoucht-Tourtit arc complex of the Sirwa inlier, the geochemical and isotopic studies of D'Lemos et al. (2006) 
on the Tazigzaout complex and of Triantafyllou et al. $(2018,2020)$ on the Bougmane complex have shown that all these rocks are the product of a polyphased magmatic activity from a magmatic arc system located in an intra-oceanic domain.

(2) Dismembered ophiolitic sequences (main topic of this study). They are both stacked via early south dipping faults on the southern arc complexes previously described, the IririTachakoucht-Tourtit complex for the Sirwa sequence and the Bougmane complex for the Bou Azzer sequences.

The Sirwa ophiolitic sequence displays metagabbroic rocks, associated with several metabasaltic clusters interpreted as the remnants of a sheeted dyke complex (El Boukhari et al., 1992, Admou and Juteau, 1998). Ultramafic units are poorly exposed. They consist of small lenses of strongly deformed serpentinized spinel-harzburgites and dunites, locally associated with pyroxenites (Chabane, 1991; El Boukhari et al., 1992). This ophiolitic sequence is extensively tectonized, marked by tectonic contacts between most of its ophiolitic terms (see Fig. 2 in Triantafyllou et al., 2020). Three major tectonic slices were recognized in the studied area, whose sole appears systematically represented by soft serpentinite bands. These sliced and stacked units were subsequently dismembered and verticalized via sinistral transpressive deformation occurring during syn- to late-orogenic shearing along the AntiAtlas Major Fault (Triantafyllou et al., 2012; Triantafyllou et al., 2020).

Geochemical studies carried out on the metabasaltic rocks of the Sirwa ophiolite show an SSZ (supra-subduction zone) affinity (e.g., El Boukhari et al., 1992) The intra-oceanic nature of this SSZ is supported by their highly positive $\varepsilon N d$ signatures $(+7.5$ to +8.8 ; Triantafyllou et al., 2020) which reflect an old depleted mantle source (but recently refertilized by subduction fluids and melts) without assimilation of WAC-derived continental material. The formation of this oceanic lithosphere was dated at $762 \pm 2$ Ma on ophiolitic plagiogranite dikes $(\mathrm{U}-\mathrm{Pb}$ on zircon, Samson et al., 2004). 
The Bou Azzer ophiolite was described in detail for the first time by Leblanc (1975). Here, we focus on the North and South Aït Ahmane sequences, close to the eponym locality. It consists of a strongly tectonized and dismembered ophiolitic assemblage exposed in the inner part of Bou Azzer inlier (Fig. 2b). The architecture of the Bou Azzer ophiolite has been studied in detail by El Hadi et al. (2010). These authors showed that the ophiolite has been structured as a complex anticlinal-shaped structure resulting from its evolution through subduction to collisional tectonics (see also Bousquet et al., 2008 and Admou et al., 2013, for more precise descriptions of the Bou Azzer ophiolite structure). The mantle section is the most represented ( 70\% of the sequence, Fig. $2 \mathrm{~b}$ ) with serpentinites deriving from spinelharzburgites and rare dunitic lenses. These largely dominant residual lithologies are associated with rare occurrences of pyroxenites and chromite pods. Mafic units are mainly metagabbros (layered and isotropic). Isotropic metagabbros are strongly deformed and retrogressed to amphibolite. Layered gabbros are marked by planar variations in modal proportions that are transposed in the main foliation trend (Figs. 3a, b). Metabasalts are exposed as metric dykes and/or undistinguished massive units. Ductile deformation is also marked in the form of boudinaged dykes along with a slight foliation subparallel to boudins. These metabasaltic massifs are interpreted as the relics of the sheeted dykes complex and as pillow lavas occasionally capping ophiolitic sequence (Leblanc, 1975, 1981). The basaltic lavas present a SSZ affinity (Bodinier et al. 1984; Naidoo et al., 1991) and as for the Sirwa ophiolitic basalts, their $\mathrm{Nd}$ isotopic signature shows positive values $(\varepsilon \mathrm{Nd}$ ranging from +6.3 and +8.1; Triantafyllou et al., 2020) in agreement with a juvenile mantle source. The Bou Azzer ophiolite was described either as a fragment of a back-arc lithosphere (Bodinier et al., 1984; Triantafyllou et al., 2018) or as a fore-arc (Naidoo et al., 1991). The only petrogeochemical study conducted on the Bou Azzer serpentinites concerns the discovery of a fossil black smoker type hydrothermal system in the North Aï Ahmane unit (Hodel et al., 
2017, 2018). Other studies carried out on these ultramafic rocks investigated spinels chemistry in serpentinites (Ahmed et al., 2005, 2009; Gahlan et al., 2006; Hodel et al., 2017). These studies tend to confirm the SSZ affinity of these oceanic remnants. The age of this section of oceanic lithosphere is still debated. No robust igneous age is available yet. El Hadi et al. (2010) proposed an age of $697 \pm 6 \mathrm{Ma}$ (U-Pb on zircons) for a gabbroic rock belonging to the Bougmane complex that they interpreted as belonging to the ophiolitic sequence based on their tectonic model. However, these rocks were recently re-interpreted as the root of the Bougmane arc complex based on their geochemical signature, the nature of its constitutive lithologies and, its high grade metamorphic evolution (up to granulite facies; Triantafyllou et al., 2018, 2020). The $697 \pm 8$ Ma age obtained by El Hadi et al (2010) is equivalent, within errors, to the 710-690 Ma ages obtained for hornblendites and related rocks of the Bougmane complex (D'Lemos et al., 2005; Triantafyllou et al., 2018). We consider that the sample dated by El Hadi et al. (2010) does not constrain the timing of oceanic spreading as represented by the Bou Azzer ophiolite at Ait Ahmane but rather characterize the second igneous phase of the Bougmane oceanic arc (Triantafyllou et al., 2018).

(3) Late Cryogenian dioritic, granodioritic to granitic intrusions cutting across the ophiolitic units were described in both Sirwa and Bou Azzer inliers. Their emplacement ages were constrained with $\mathrm{U}-\mathrm{Pb}$ geochronology on magmatic zircon grains and range between 660 and 640 Ma (Inglis et al., 2004; El Hadi et al., 2010; Walsh et al., 2012; Blein et al., 2014; Triantafyllou et al., 2016). 
KHZAMA SEQUENCE (SIRWA OPHIOLITE)
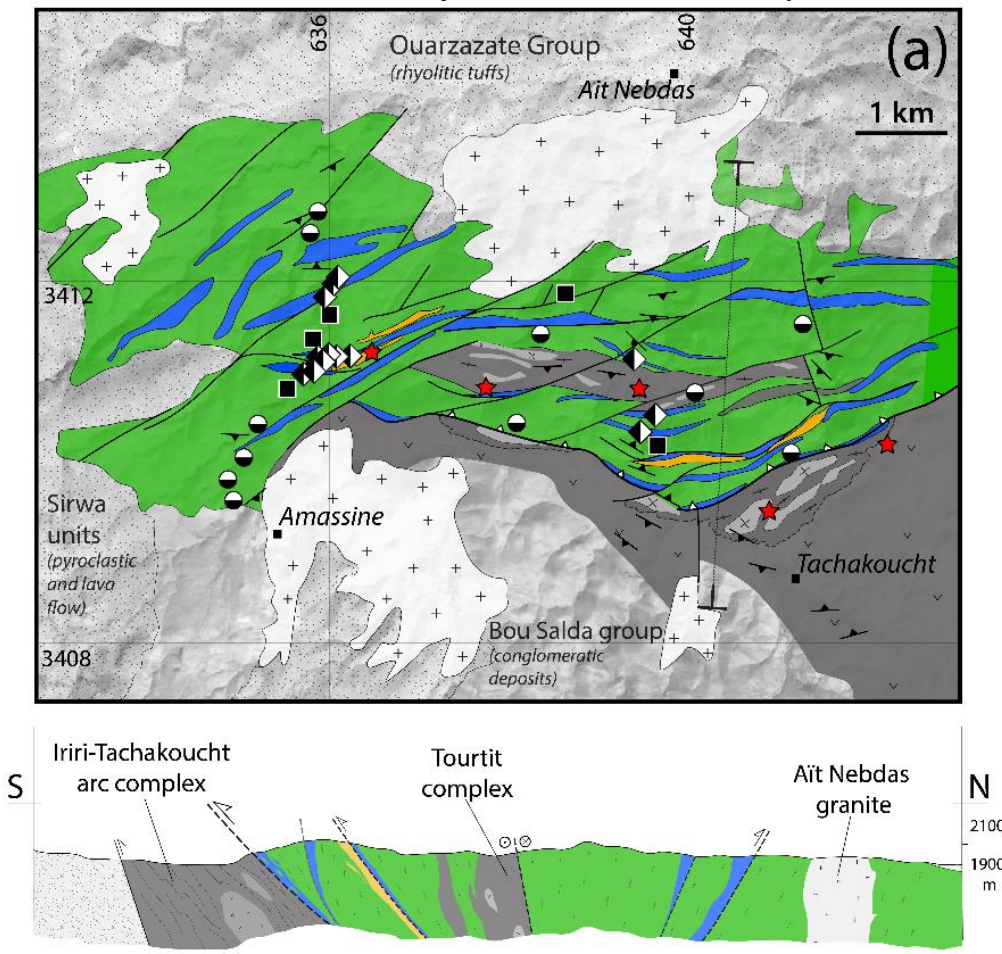

\section{AÏT AHMANE SEQUENCE (BOU AZZER OPHIOLITE)}

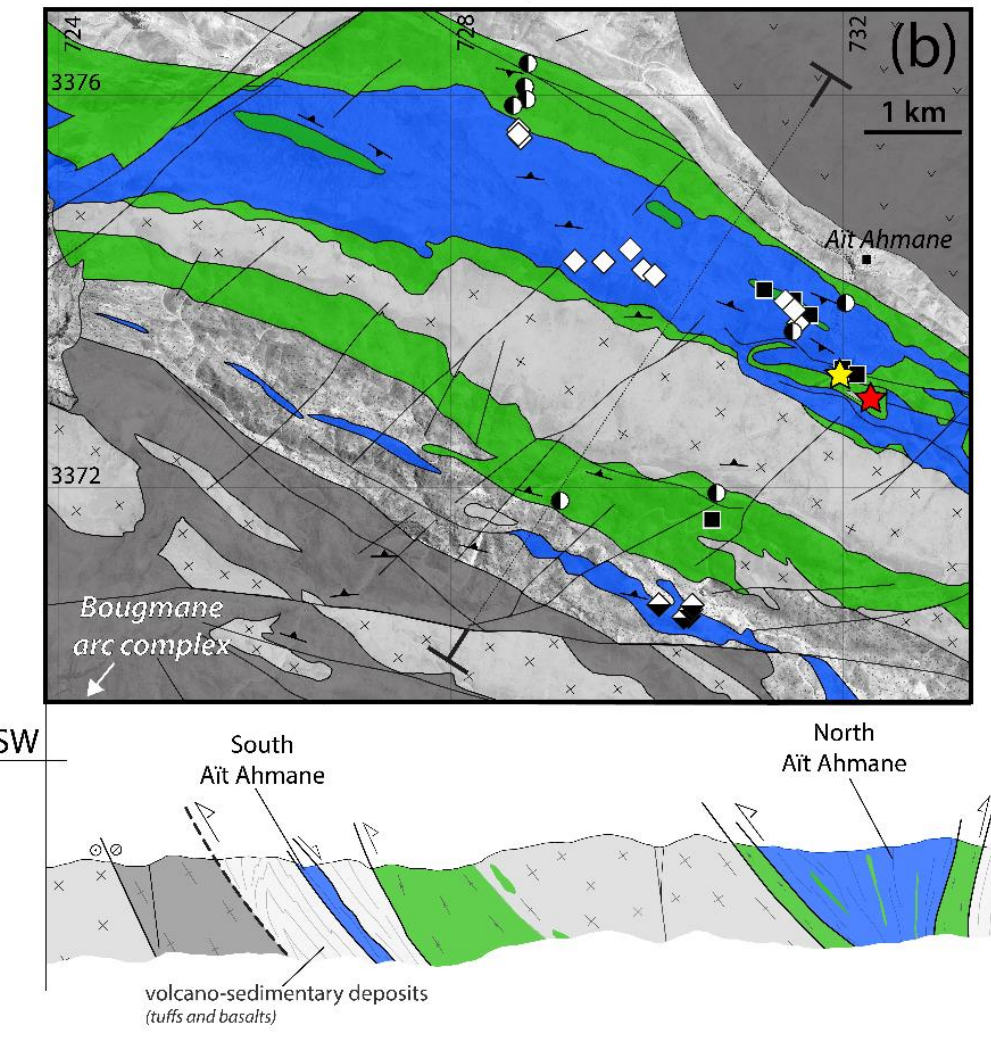

\section{Ophiolitic complexes}

Ophiolitic ultramafics (pyroxenite and serpentinized peridotites)

Ophiolitic mafics (basalts, layered and isotropic gabbros)

Ophiolitic plagiogranite

\section{Oceanic arc complexes}

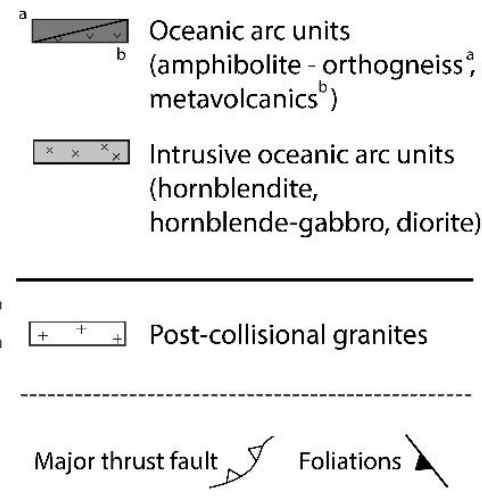

\section{Sampling}

$D \bigcirc$ Metabasalts samples

- Metagabbros samples

$\diamond \triangle$ Serpenitinites samples

Su-Pb dating (literature)

U-Pb dating (this study)

\section{Projection:}

WGS84 UTM 29N (XY in km)

Basemap: SPOT image, CNES

Elevation profile: Aster Gdem v2

Figure 2: (a) Simplified geological map and cross section of the Sirwa ophiolite (Khzama sequence) modified from Triantafyllou et al. (2016). (b) Simplified geological map and cross section of the Ait Ahmane sequences of the Bou Azzer 
ophiolite and associated plutono-metamorphic (intra-oceanic arc) units to the south (combining field information of this study and from Admou et al., 2013). Background gray scale images for are grayscale SPOT images product (CNES) and elevation profiles were extracted from Aster Gdem v2 topographical data. KMZ versions of these maps including samples locations have been generated using Geolokit app (Triantafyllou et al., 2017) and can be found in the Supplementary Materials 1.

\section{Field relations and samples description}

Representative samples of metabasalts, metagabbros (mafic units) as well as serpentinized peridotites (ultramafic units) were collected from both the Sirwa and Bou Azzer ophiolites (see Fig. 2a, b).

For the Sirwa ophiolite, sixteen serpentinites, four metagabbros and nine metabasalts samples were collected in the Khzama area. The Khzama serpentinites were sampled in two ultramafic massifs located northward of the Amassine village (SRW series) as well as two other massifs exposed on both sides of the Tourtit village (KK series). Most of the metabasaltic and metagabbroic rocks were sampled in the western Amassine valley. Additional mafic samples were collected from both central and eastern valleys of the area to ensure representativity and coverage on the Sirwa ophiolitic sequence (Fig. 2a).

Two main mafic-ultramafic assemblages were recognized and sampled in the Bou Azzer ophiolite (Fig. 2b): (i) the Northern Aït Ahmane unit is located in the central part of the Bou Azzer-El Graara inlier. It is bordered by isotropic metagabbroic and metabasaltic units to the North and by isotropic and layered metagabbros as well as metabasalts and the intrusive Aït Ahmane quartz-diorite to the South (Fig. 2b); (ii) The Southern Ait Ahmane unit consists of an alignment of small dismembered serpentinite lenses outcropping to the south of the inlier into Upper Cryogenian volcano-sedimentary formations (Admou et al., 2013). We discarded serpentinites displaying obvious alteration features in the field and conducted our sampling campaign away from zones were carbonation and/or hydrothermal overprint have been 
described by Hodel et al. $(2017,2018)$ for the North Aït Ahmane unit. Nine metabasalts and seven metagabbros were sampled in the Northern Aït Ahmane area. The North Aït Ahmane ultramafic unit was already sampled by Hodel et al. (2018) who studied variously hydrothermalized serpentinites and associated massive magnetite veins. We sampled five additional serpentinites from this unit. Sixteen serpentinites, two metabasalts and one metagabbro were also sampled in the Southern Aït Ahmane unit following a N-S profile (Fig. 2b). All the analytical methods and protocols are detailed in the appendices (see A.1. for Analytical methods).

\section{Petrography and mineral chemistry}

\subsection{Mafic units}

Metagabbroic units from the Khzama (Sirwa) and Aït Ahmane (Bou Azzer) ophiolitic units consist of amphibolites with fine- to medium-grained equigranular, granoblastic texture. Isotropic as well as layered metagabbros were observed in both units. The latter are characterized by centimetric to pluri-centimetric layering with variable plagioclase-amphibole modal proportions (Fig. 3a).

The Khzama metagabbros are made of tschermakitic amphibole $(\mathrm{Mg \#}>0.53, \mathrm{Si}<6.5 \mathrm{apfu}$, see table $\mathrm{X}$ ) and retrogressed andesine-oligoclase plagioclase $(\mathrm{xAb} \sim 60-80 \mathrm{~mol} \%$; $\mathrm{xAb}=$ $\mathrm{Na} /[\mathrm{Na}+\mathrm{Ca}+\mathrm{K}]$ on molar basis) with accessory titanite-ilmenite, clinozoisite, apatite and occasional carbonate and quartz. The Ait Ahmane metagabbros share numerous petrographical similarities with the Khzama samples (Fig. 3a, b). They contain calcic amphibole with tschermakitic to $\mathrm{Mg}$-hornblende composition $\left(\mathrm{Mg} \#>0.51, \mathrm{xSi}_{\mathrm{A}}\right.$ ranging between 6.2 and $7.5 \mathrm{apfu}$; Leake et al., 2004) with few brownish cores with pargasitic composition (see Supplementary Material 2 for EPMA analyses). Retrogressed plagioclases range from andesine to albite compositions $(48<\mathrm{xAb}<91 \mathrm{~mol} \%)$. Accessory phases are 
titanite, apatite, zircon and magnetite. Few metagabbros show relics of higher-grade pressuretemperature conditions marked by garnet pseudomorphosis (now totally retrogressed in chlorite-amphibole assemblage; Fig. 3b) along with amphibole cores with pargasitic compositions.

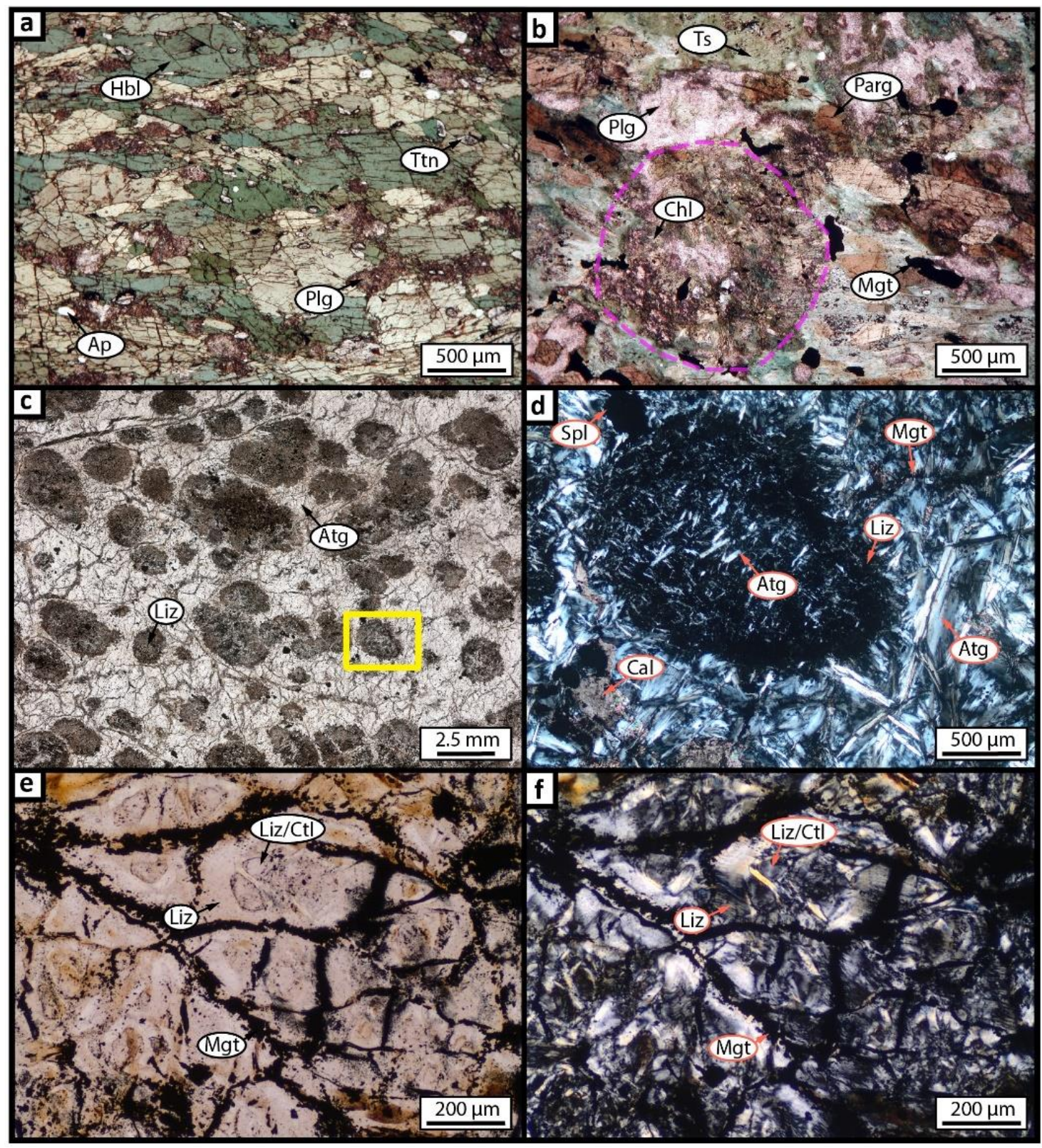

Figure 3: (a) Microphotograph of melanocratic layer in L72 layered metagabbro used for U-Pb dating (hornblende + retrogressed plagioclase + accessory apatite and titanite) (b) Microphotograph of $L 68$ isotropic metagabbro showing relics of high grade paragenesis (i.e. pargasite and see dashed pink line for garnet pseudomorphosis). (c) High resolution scan of a thin section portion of a South Aït Ahmane serpentinite showing the dark lizardite/chrysotile nodules in clearer antigorite (in plane-polarized light). The yellow rectangle corresponds to the zoomed view on the photomicrograph to the right (in d). (d) Photomicrograph of a dark lizardite nodule in clearer interpenetrated antigorite blades. Note the presence of calcite in the 
left down corner. (e, f) Photomicrographs of a North Aït Ahmane serpentinite displaying a pseudomorphic lizardite/chrysotile mesh texture with abundant magnetite concentrated in mesh rims (e in plane-polarized light and $f$ in cross-polarized light). Abbreviations correspond to: Hbl: hornblende, Plg: plagioclase, Ttn: titanite, Ap: apatite, Chl: chlorite, Liz: lizardite, Atg: antigorite, Ctl: chrysotile, Spl: spinel, Mgt: magnetite, Cal: calcite.

\subsection{Ultramafic units}

Serpentinites from the Khzama unit display a non-pseudomorphic texture, composed of interpenetrating antigorite blades (serpentinites varieties were determined using RAMAN spectroscopy, see Appendix A.1.1) (Fig. 3c, d). Some bastites (serpentinized pyroxenes) are sometimes recognizable through preserved original cleavages, often highlighted by alignments of magnetite grains. A darker phase occurring between antigorite blades is composed of a lizardite/chrysotile assemblage (Fig. 3c, d). In few samples, this lizardite/chrysotile assemblage forms circular nodules that reach several hundreds of micrometers in diameter (Fig. 3c, d). Given the degree and texture of serpentinization, it is almost impossible to determine the modal composition of the former peridotite.

Serpentinites from the South Aït Ahmane unit display similar petrographic characteristics to those from the Khzama unit. They are also mainly composed of interpenetrated antigorite blades (Fig. 3c, d) but lizardite/chrysotile darker nodules are much more present, even at the macroscopic scale (measuring from 0.5 to $4 \mathrm{~mm}$, Fig. 3c, d). When compared to the serpentinites from the two other units, they are richer in carbonate phases (Fig. 3d). Carbonates are frequently associated with chrysotile in late veins or form patches into the antigoritic matrix (Fig. 3d).

Finally, serpentinites from the North Ait Ahmane unit display a pseudomorphic texture with a serpentine mesh formed after olivine retrogression (Fig. 3e, f) and bastites formed after orthopyroxene (about 10 to $20 \%$ of the modal composition). 
Spinel is the only pristine mineral preserved from serpentinization in all the studied ultramafic rocks. Spinel grains are very weakly altered in the Khzama and South Aï Ahmane serpentinites despite the fact that antigorite is the largely dominant serpentine variety reported in these serpentinites. Spinel grains are euhedral to subhedral. They are rimmed by a thin ferritchromite and/or $\mathrm{Cr}(+\mathrm{Ni})$-bearing magnetite aureole (Fig. 4a, b). The degree of alteration is much more variable in the North Ait Ahmane serpentinites, mainly due to the intense hydrothermal activity that affected these serpentinites (Hodel et al., 2017, 2018). For mineral chemistry, we only considered the less affected samples and analyzed only the preserved spinel cores of the least altered grains (Fig. 4c). 


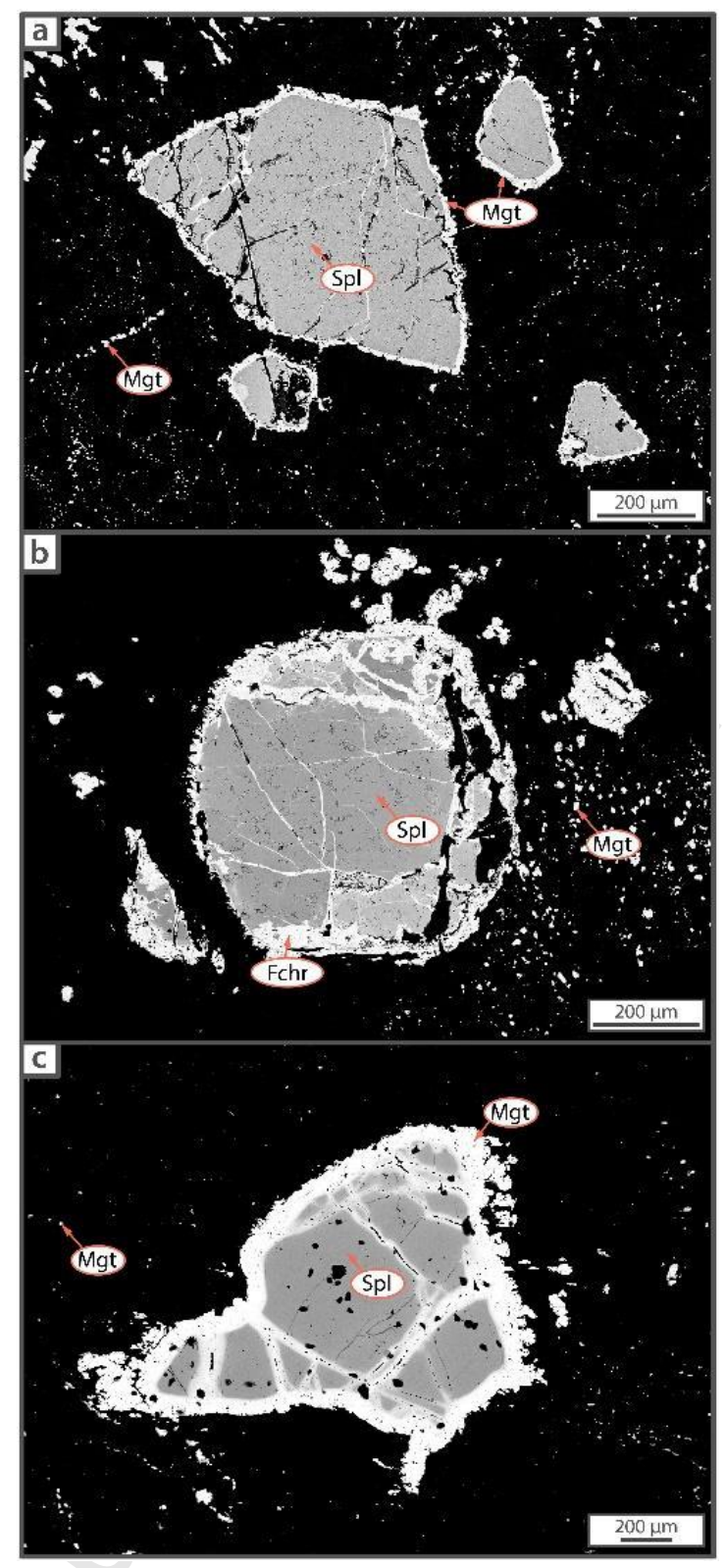

Figure 4: BSE (Back Scattered Electron) images of euhedral to subhedral spinel grains partially altered to ferritchromite and $\mathrm{Cr}(\mathrm{Ni})$-rich magnetite (a) from the Khzama serpentinites (b) from the South Aït Ahmane serpentinites and (c) from the North Ait Ahmane serpentinites.

Unaltered spinel cores show intermediate to high $\mathrm{Cr} \#(\mathrm{Cr} \#=\mathrm{Cr} /[\mathrm{Cr}+\mathrm{Al}]=0.44-0.81)$ and low to high $\mathrm{Mg \#}$ values $\left(\mathrm{Mg} \#=\left[\mathrm{Mg} /\left(\mathrm{Mg}+\mathrm{Fe}^{2+}\right)\right]=0.25-0.73\right)($ Fig. 5a, see also Supplementary material 3). Spinels from the Khzama serpentinites display a narrow Cr\# and Mg\# range, varying from 0.68 to 0.81 and 0.26 to 0.57 , respectively. Spinels from the South and North Aït Ahmane units present more variable compositions with $\mathrm{Cr} \#$ and $\mathrm{Mg \#}$ ranging from 0.44 to 0.79 and 0.34 to 0.73 , respectively. For the three units, these compositions point to a highly 
depleted protolith (more than $25 \%$ of melt extraction in most cases; Arai, 1994) hence, corresponding to the composition of spinel found in subduction related peridotites (Fig. 5a). Spinels from Aït Ahmane serpentinites have very low $\mathrm{TiO}_{2}$ contents $(<0.1 \mathrm{wt} \%)$ consistent with a highly depleted precursor while the spinels from the Khzama serpentinites are characterized by higher $\mathrm{TiO}_{2}$ contents $(0.10-0.26 \mathrm{wt} \%)$, reflecting prior-serpentinization melt/rock interactions, i.e. refertilization processes (Fig. 5b).
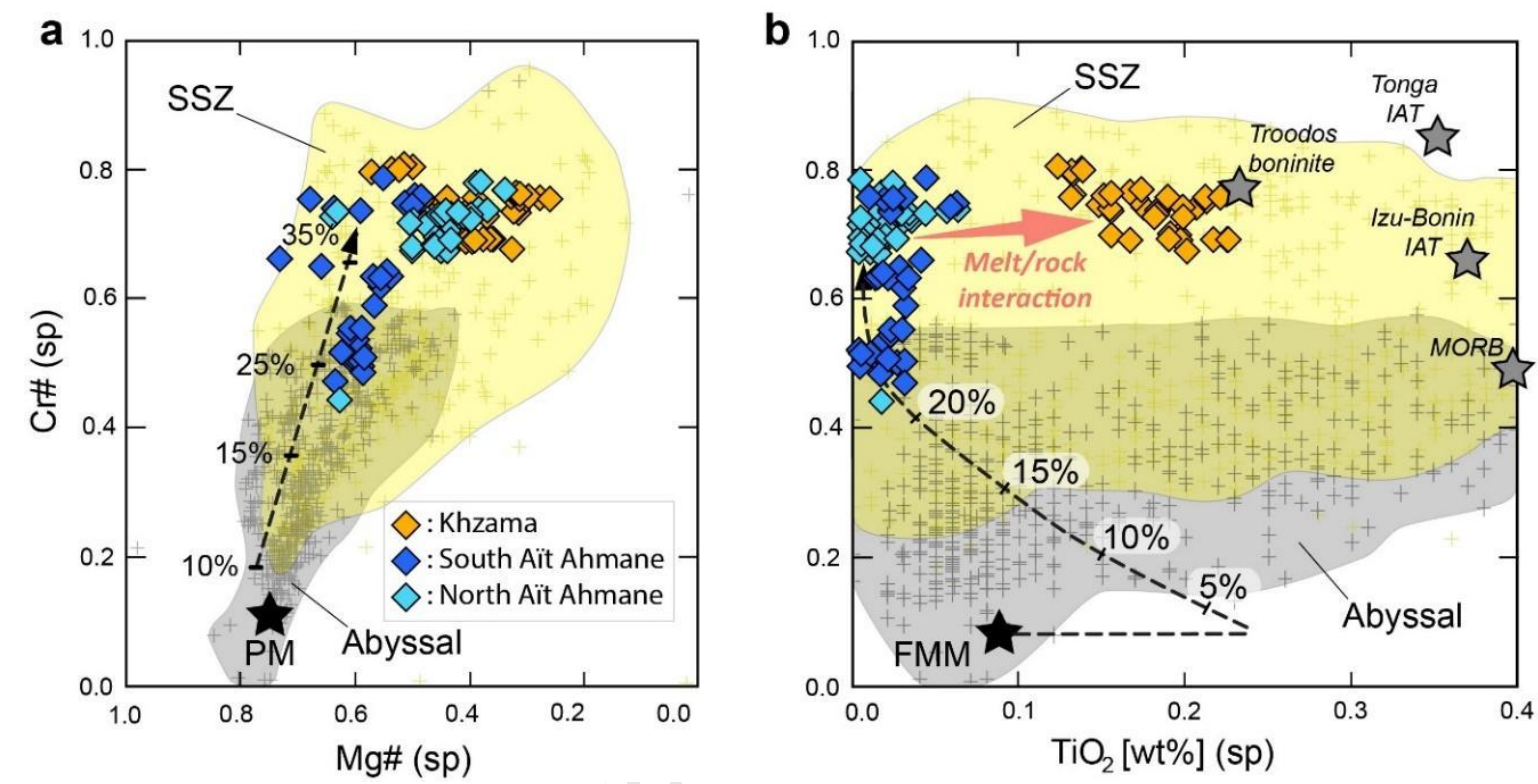

Figure 5: Spinel compositions in serpentinites from the Aït Ahmane (Bou Azzer) and Khzama (Sirwa) complexes (104 grains of 23 samples). (a) Compositional relationship between $\mathrm{Cr} \#(=\mathrm{Cr} /[\mathrm{Cr}+\mathrm{Al}])$ and $\mathrm{Mg \#}\left(=\mathrm{Mg} /\left[\mathrm{Mg}+\mathrm{Fe}^{2+}\right]\right)$ of spinels in the Ait Ahmane and Khzama serpentinites. Only primary cores analyses are represented here and have been considered for

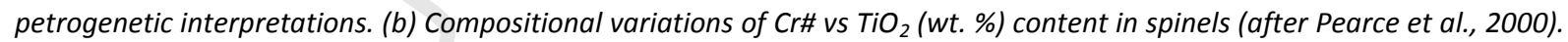
Abyssal peridotites field is from Warren (2016), SSZ (Supra Subduction Zone) peridotites field is from Ishii et al. (1992) and Parkinson and Pearce (1998). Partial melting trend is from Arai (1994).

\section{Whole-rock chemistry}

\subsection{Metabasalts}

Major and trace elements concentrations measured on mafic rocks are provided in Supplementary material 4. 
Major elements. Metabasaltic samples from the Khzama and Aï Ahmane ophiolitic units are subalkaline basalts and basaltic andesites $\left(\mathrm{SiO}_{2}\right.$ content $47-54 \mathrm{wt} \%$; median value at 50.3 $\mathrm{wt} \% ; \mathrm{Na}_{2} \mathrm{O}+\mathrm{K}_{2} \mathrm{O}<5.9 \mathrm{wt} \%$; median at $4.6 \mathrm{wt} \%$ ). They show tholeiitic affinity with only a few samples displaying a calk-alkaline signature $(\mathrm{FeO} * \mathrm{MgO}$ ranges between 0.9 to $2.6 \mathrm{wt} \%$; median at $2.1 \mathrm{wt} \%)$. Subalkaline signature is also confirmed by their low $\mathrm{Nb} / \mathrm{Y}$ ratios $(<0.26$; Winchester and Floyd, 1977) except for one sample (AH25). The Aït Ahmane metabasalts show relatively low $\mathrm{TiO}_{2}$ contents which typically corresponds to an arc-related Ti-poor lavas signature. The Sirwa metabasalts show higher Ti values pointing to a transitional composition between MORB and back-arc mafic lavas.

Trace element. Two types of metabasalts were distinguished based on their REE patterns. Both types occur in the Sirwa and the Ait Ahmane ophiolitic massifs:

(i) The first type is characterized by relatively low REE contents (6 to 15 times the chondritic values; median at 8$)$, flat MREE to HREE pattern $\left([\mathrm{Dy} / \mathrm{Yb}]_{\mathrm{N}}\right.$ median at 0.99; Fig. 6a) and flat to depleted LREE profiles ([La $]_{\mathrm{N}}$ values range from 6.4 to 9.1 ) comparable to N-MORB signature. They are enriched in LILE (Large Ion Lithophile Elements: Cs, Rb, Ba, Th) compared to NMORB reference value $\left([\mathrm{Ba}]_{\text {N.NMORB }}\right.$ and $[\mathrm{Th}]_{\text {N.NMORB }}$ ranging from 12.3 to 49.0 and 1.6 to 3.0, respectively with median values at 13.9 and 2.5) (Fig. 6b). Sr contents are variable but correlated with $\mathrm{Eu}$ variations and reflecting plagioclase fractionation. HFSE (High Field Strength Elements) concentrations are low compared to NMORB. Along with the REE signature described above, these rock analyses are consistent with a mantle source strongly depleted in incompatible elements and/or affected by high degrees of mantle melting. Their $\mathrm{Th} / \mathrm{Nb}$ ratios are comprised between 0.03 and 0.42 , similar to the expected $\mathrm{N}-\mathrm{MORB}$ value ( 0.04; Sun and McDonough, 1989).

(ii) The second type is marked by higher REE abundances (15 to 35 times the chondritic values; median at 22), patterns showing significant fractionation between MREE and HREE 
$\left([\mathrm{Dy} / \mathrm{Yb}]_{\mathrm{N}}\right.$ median at 1.34$)$ and generally higher LREE content $\left([\mathrm{La}]_{\mathrm{N}}\right.$ range from 19.3 to 82.4; Fig. 6c, d). These REE signatures are very comparable to island arc tholeiitic basalt patterns (Fig. 6c). The N-MORB-normalized multi-elements patterns (Fig. 6d) show higher values in incompatible elements than for type-1 metabasalts. Enrichments in LILE elements are variable but mostly above MORBs $\left([\mathrm{Ba}]_{\text {N.NMORB }}\right.$ and $[\mathrm{Th}]_{\text {N.NMORB }}$ ranging from 1.2 to 158.4 and 1.6 to 21.4 , respectively with median values at 20.2 and 6.0). Most samples show negative anomalies in $\mathrm{Nb}-\mathrm{Ta}\left([\mathrm{Nb}]_{\mathrm{N} . \mathrm{NMORB}}\right.$ values vary between 0.9 and 3.3$)$ and slight negative anomalies in $\mathrm{Zr}-\mathrm{Hf}\left([\mathrm{Zr}]_{\mathrm{N} . \mathrm{NMORB}}\right.$ values: $\left.0.7-2.2\right)$. The $\mathrm{Th} / \mathrm{Yb}$ ratio is a useful proxy to quantify the amount of slab-derived component into depleted MORB mantle (Pearce and Stern, 2006). Both types of metabasalts show a strong influence of subduction component to the MORB array (ranges of $\mathrm{Th} / \mathrm{Yb}$ : $0.07-1.07$ for $\mathrm{Nb} / \mathrm{Yb}$ : $0.6-3.4$; range of $\mathrm{Ti} / \mathrm{Yb}: 1208$ 4227 and Zr/Yb: 11 - 56 for La/Yb: 0.7 - 4.9; see Fig. 7a, b, c).
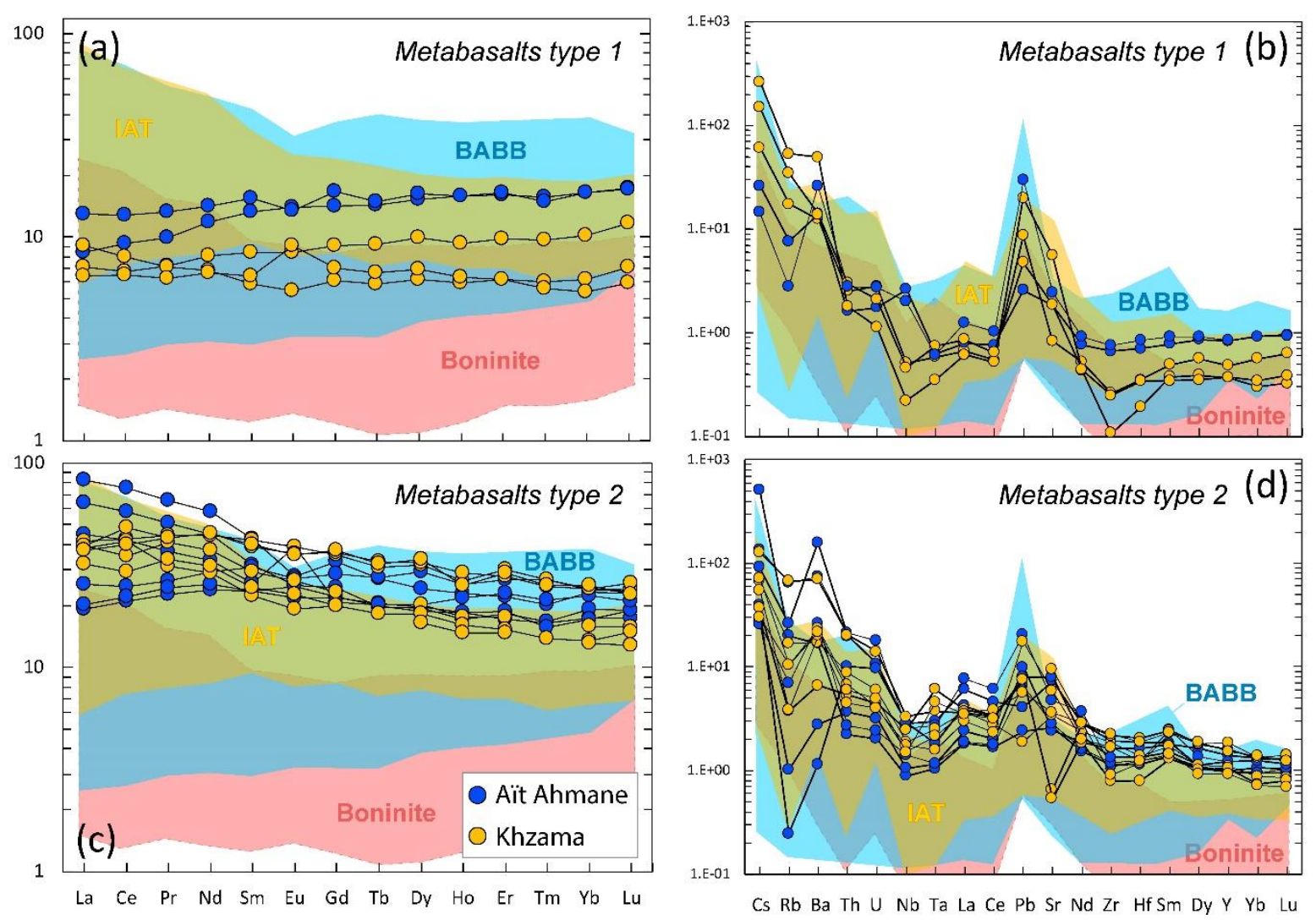
Figure 6: $(a, c)$ Chondrite-normalized REE patterns of the Khzama and the Ait Ahmane metabasalts. Chondrite values are from Barrat et al. (2012). (b, d) NMORB-normalized multi-element patterns for the Khzama and the Ait Ahmane metabasalts. NMORB values are from Sun and McDonough (1989). IAT (Island Arc Tholeiite) and BABB (Back-Arc Basin Basalts) compositions are from PetDB (https://www.earthchem.org/petdb) and boninites compositions are from the GEOROC database (http://georoc.mpch-mainz.gwdg.de).
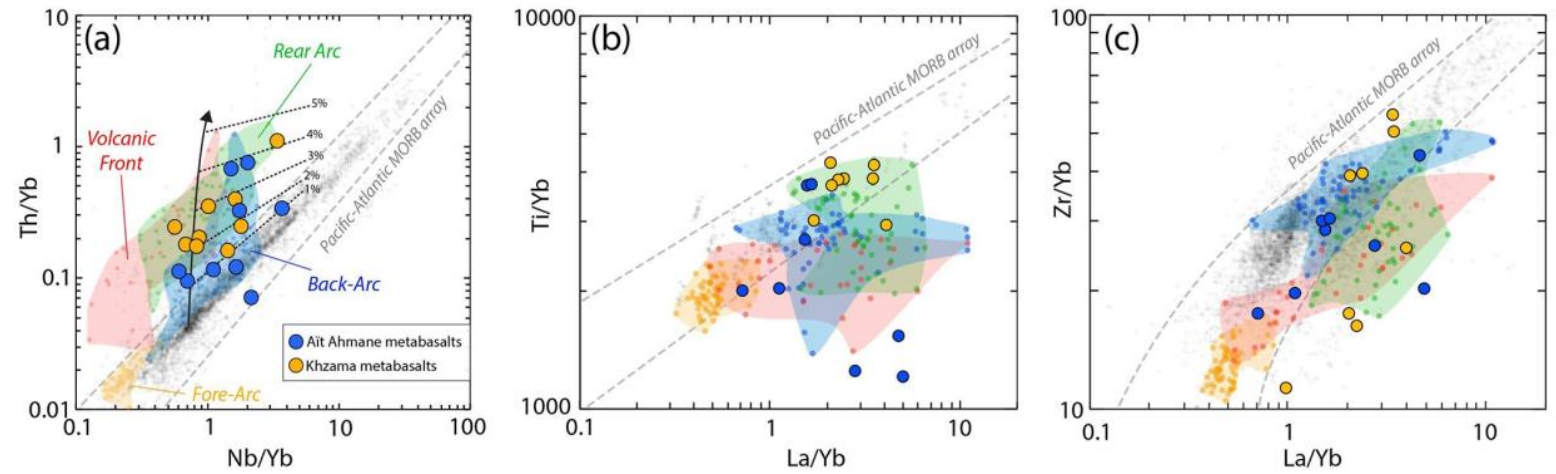

Figure 7: $T h / Y b, T i / Y b$ and $\mathrm{Zr} / \mathrm{Yb}$ versus $\mathrm{Nb} / \mathrm{Yb}$ or $\mathrm{La} / \mathrm{Yb}$ diagrams for the Ait Ahmane and Khzama metabasalts. Note the departure from the mantle array indicating the presence of a subduction component (higher Th/Yb, lower Ti/Yb and Zr/Yb; see text for details). Fields of IzU-Bonin-Mariana (IBM) volcanic front (red) and back-arc (blue), rear arc (green) and forearc (yellow) basalts composition are gathered from PetDB (https://www.earthchem.org/petdb). Percentages of subduction contamination are from Pearce (2008). The mantle array extends from below normal-mid ocean ridge basalt (N-MORB) through intraplate basalts to ocean island basalts (OIB). Light grey dots are MORB values gathered from PetDB (https://www.earthchem.org/petdb).

\subsection{Metagabbros}

Major elements. Metagabbros in Khzama and Aï Ahmane ophiolitic sequences show relatively low $\mathrm{SiO}_{2}(41.8-51.1$ wt. $\%$ ) contents, high $\mathrm{MgO}$ (median at 11.6 wt.\% and range between 7.04 and 24.6 wt\%) and $\mathrm{CaO}(10.1-19.9$ wt.\%) contents along with relatively low $\mathrm{TiO}_{2}$ contents $\left(0.72\right.$ wt. $\% \mathrm{TiO}_{2}$, in average).

Trace element. Two types of metagabbros can be distinguished (Fig. 8): (i) Type 1 metagabbros have only been observed in the northern Aït Ahmane ophiolitic sequence. They show relatively high content in incompatible elements (REE concentrations are 16 to 27 chondritic values). REE patterns are relatively flat with a slight depletion in LREE $\left([\mathrm{La} / \mathrm{Sm}]_{\mathrm{N}}\right.$ 
ranging between $0.41-0.69 ;[\mathrm{Gd} / \mathrm{Yb}]_{\mathrm{N}}$ between $\left.1.06-1.18\right)($ Fig. $8 \mathrm{a})$. Their trace elements composition is very similar to $\mathrm{N}-\mathrm{MORB}$, with relative enrichment in $\mathrm{Cs}, \mathrm{Rb}, \mathrm{Ba}, \mathrm{Nb}$ and $\mathrm{Pb}$ (Fig. 8b). They show typical gabbro signature from the middle to upper crustal section of oceanic crust (see comparison with Samail 'high-gabbros' on Fig. 8a). (ii) Type 2 metagabbros are marked by lower abundances in REE and other incompatible elements (REE between 0.1 and 1 time chondritic values; $\mathrm{Nb}$ : 0.01-2.95 ppm, $\mathrm{Zr}: 0.01-0.05 \mathrm{ppm}, \mathrm{Y}: 0.03-$ $0.19 \mathrm{ppm}$ ) (Fig. 8). REE patterns show strong LREE depletion relative to MREE ([La/Sm $]_{\mathrm{N}}$ ratios ranges between 0.18 and 0.83$)$ and flat MREE-HREE trends $\left([\mathrm{Gd} / \mathrm{Yb}]_{\mathrm{N}}\right.$ ratios between 0.85 and 1.17; Fig. 8a). Slight positive Eu anomalies ([Eu/Eu* $]_{\mathrm{N}}: 1.03$ to 1.72$)$ are correlated with Sr contents and attributed to plagioclase accumulation. Type 2 metagabbros show typical cumulative signature, similar to those from the Samail lower to middle crust gabbros (Fig. 8a).

The layered metagabbro dated in this study (sample L72, see section 6) belongs to the type 1 group. Both type 1 and type 2 metagabbros from the Sirwa and the Bou Azzer ophiolite show oceanic-like signature, attesting of their genetic link with the ophiolitic sequence. Moreover, they display different geochemical signature compared to mafic rocks forming the oceanic arc complex to the south (e.g. Bougmane complex in Bou Azzer and Iriri complex in Sirwa; Triantafyllou et al., 2018). Specifically, type 1 and type 2 ophiolitic metagabbros are characterized by rather low $\mathrm{La} / \mathrm{Yb}$ ratios (mean value at 0.42 and range between 0.17 and 0.70) compared to their arc-related counterpart (mean value at 1.68 and range from 1.05 to 3.1). 

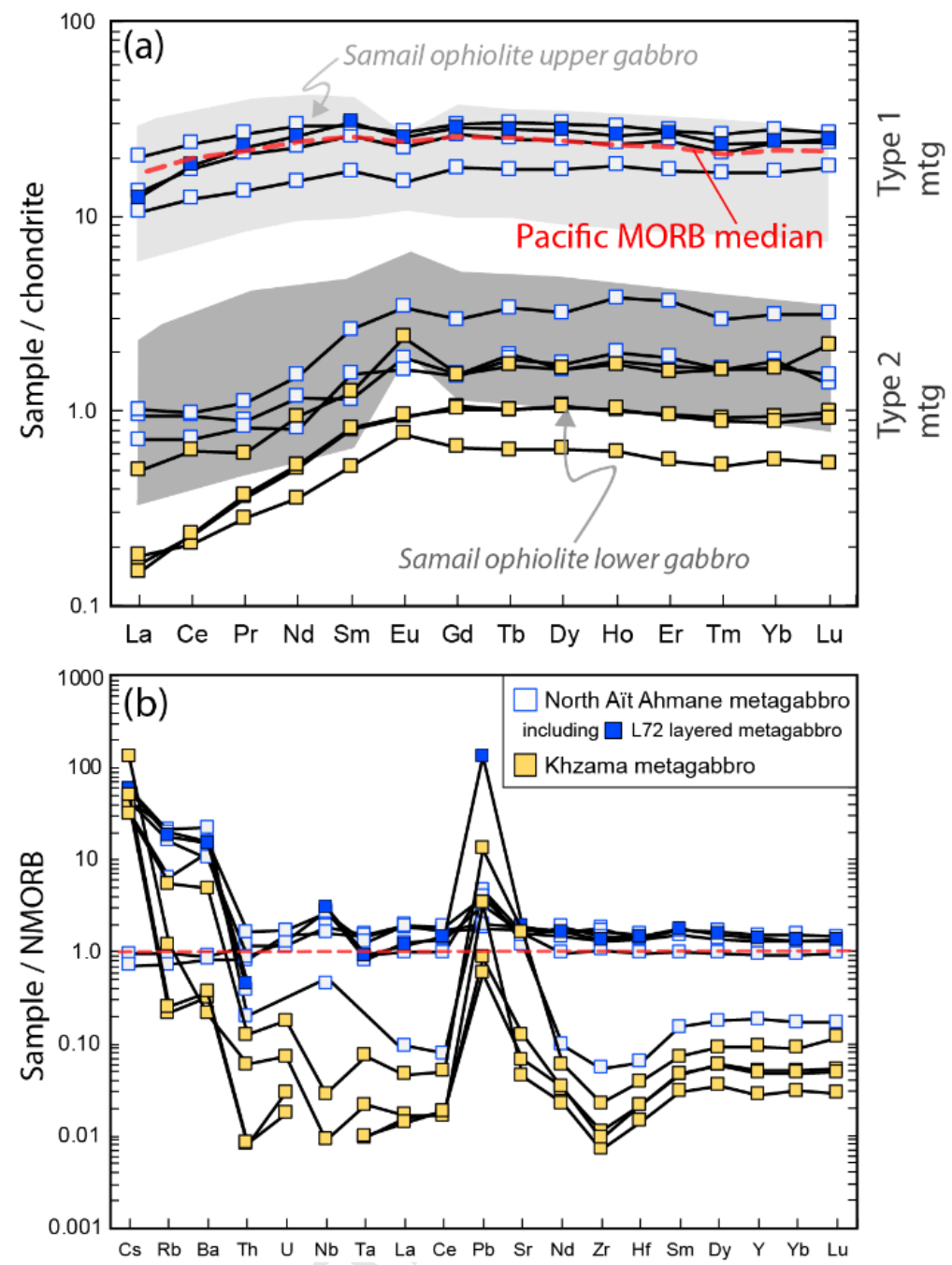

Figure 8: (a) Chondrite-normalized REE patterns and (b) N-MORB-normalized multi-element patterns for the Khzama and of the northern Aït Ahmane metagabbroic rocks. Dated layered metagabbro (sample L72) is represented to show its NMORB affinity. Chondrite and NMORB normalizing values are from Barrat et al. (2012) and Sun and McDonough (1989) respectively. Samail ophiolites' (Oman) low and upper crust gabbro fields are from Pallister and Knight (1981) and Kelemen et al. (1997). Median composition of Pacific Oceanic Ridge Basalt (red dashed line) is calculated based on PetDB (https://www.earthchem.org/petdb) database.

\subsection{Serpentinites}

Major and trace elements concentrations measured in ultramafic rocks are provided in Supplementary material 5 .

Major elements. All the analyzed serpentinites show high LOI (Loss On Ignition) values, from 11.3 to $12.9 \mathrm{wt} \%$, reflecting the high degree of serpentinization. Whole-rock major 
oxides contents were recalculated on a volatile-free basis in order to compare our results with the compositions reported for other serpentinites and variously serpentinized peridotites in the literature (Figs. 9 and 10).

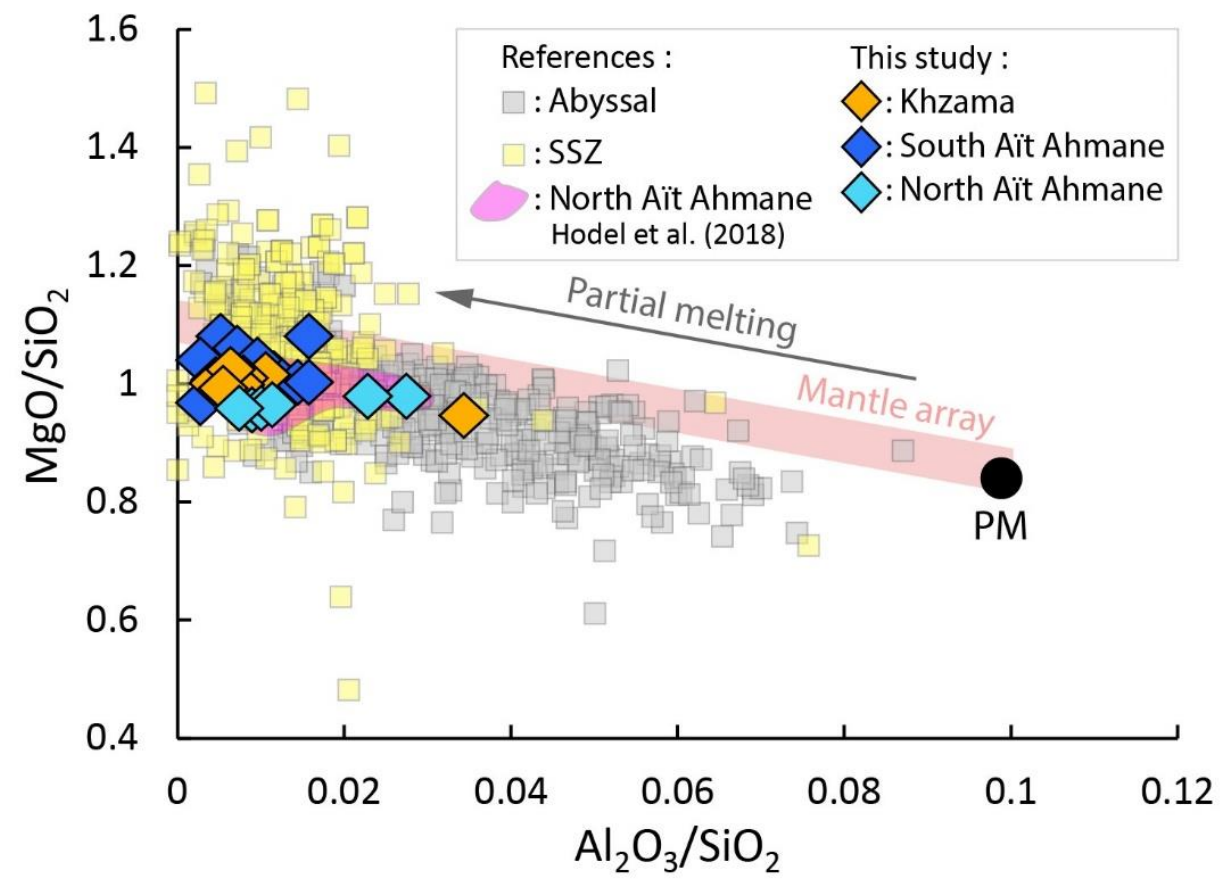

Figure 9: $\mathrm{MgO} / \mathrm{SiO}_{2}$ vs. $\mathrm{Al} / 2 \mathrm{O}_{3} / \mathrm{SiO}_{2}$ ratios for the Khzama and Aït Ahmane (South and North) serpentinites. The pink domain corresponds to the North Ait Ahmane variously hydrothermalized serpentinites of the Hodel et al. (2018) study. Data for abyssal peridotites are from Snow and Dick (1995), Casey (1997), Niu (2004), Paulick et al. (2006), Godard et al. (2008), Augustin et al. (2012), Boschi et al. (2013), Andreani et al. (2014), Chen et al. (2015). Data for SSZ (Supra Subduction Zone) peridotites are from Ishii et al. (1992), Parkinson and Pearce (1998), Pearce et al. (2000), Savov et al. (2005, 2007), Marchesi et al. (2006, 2009) Kodolányi et al. (2012). Mantle array is from Jagoutz et al. (1979) and Hart and Zindler (1986). Primitive mantle values are from McDonough and Sun (1995).

Most of the analyzed serpentinites plots slightly under the mantle array (Jagoutz et al., 1979; Hart and Zindler, 1986) in a $\mathrm{MgO} / \mathrm{SiO}_{2}$ versus $\mathrm{Al}_{2} \mathrm{O}_{3} / \mathrm{SiO}_{2}$ diagram (Fig. 9). Such feature is usual for highly serpentinized peridotites. It is explained either by $\mathrm{Mg}$ loss during low temperature seafloor alteration (Snow and Dick, 1995; Niu, 2004; Kodolányi et al., 2012; Deschamps et al., 2013) or by Si addition through fluid/rock interactions (e.g., Bach et al., 2004; Harvey et al., 2014; Boschi et al., 2013; Malvoisin, 2015). Nonetheless, this alteration 
signature is not dramatic in our samples, making reasonable to use $\mathrm{MgO}$ and $\mathrm{SiO}_{2}$ concentrations as fertility indicators for their ultramafic protoliths. Most of the Khzama and Aït Ahmane serpentinites display a rather narrow range of high $\mathrm{MgO} / \mathrm{SiO}_{2}$ and low $\mathrm{Al}_{2} \mathrm{O}_{3} / \mathrm{SiO}_{2}$ ratios varying from 0.96 to 1.08 and 0.03 to 0.016 respectively, characteristic of highly depleted peridotites. Three samples from the Khzama and the North Ait Ahmane units stand out by showing higher $\mathrm{Al}_{2} \mathrm{O}_{3} / \mathrm{SiO}_{2}$ ( 0.034 for the sample from Khzama and 0.023 and 0.028 for the samples from Aït Ahmane) for similar $\mathrm{MgO} / \mathrm{SiO}_{2}$ (0.94 for the sample from Khzama and 0.98 for the samples from Aït Ahmane) testifying to a less depleted (or more refertilized) protolith for these three samples.

Khzama and Aït Ahmane (North and South units) serpentinites are Al-poor (0.12-0.69 wt\% for most of the samples and 1.02-1.53 wt\% for the three samples that display higher $\mathrm{Al}_{2} \mathrm{O}_{3} / \mathrm{SiO}_{2}$ ratios mentioned above, Fig. 10a). They show a wide range of $\mathrm{MgO}$ content (from 42.13 to $45.63,41.61$ to 45.73 and 41.84 to 43.73 wt\% for the Khzama, South Aït Ahmane and North Aït Ahmane respectively), possibly reflecting either diverse protolith fertility or Mg loss during low temperature seafloor alteration (e.g., Snow and Dick, 1995; Niu, 2004). $\mathrm{FeO}_{\text {Total }}$ is highly variable $(7.31-13.72 \mathrm{wt} \%, 6.32-10.22 \mathrm{wt} \%$ and $9.52-13.56 \mathrm{wt} \%$ for Khzama, South Aït Ahmane and North Aït Ahmane respectively). Hodel et al. (2017, 2018) showed that the hydrothermal activity affecting the North Aït Ahmane serpentinites led to an important iron mobilization in the serpentinites (see pink domain in Fig. 10b), involved in the precipitation of massive magnetite veins in cracks (see also Gahlan et al., 2006).

Whole-rock $\mathrm{CaO}$ content is known to be strongly affected by the serpentinization and associated carbonation reactions (Miyashiro et al., 1969; Coleman and Keith, 1971; Janecky and Seyfried, 1986; Palandri and Reed, 2004; Iyer et al., 2008). The carbonation of the South Aït Ahmane antigoritic serpentinites (Fig. 3d) results in high to very high $\mathrm{CaO}$ concentrations (0.04-7.64 wt\%, Fig. 10c). The serpentinites from the Khzama and North Aït Ahmane units, 
which do not exhibit petrographic evidence of carbonation, show lower $\mathrm{CaO}$ concentrations, comprised between 0.03 and $0.96 \mathrm{wt} \%$. These latter values are consistent with the harzburgitic and dunitic nature of their protolith. $\mathrm{SiO}_{2}$ contents are also variable (42.31-45.00 wt $\%, 40.67-47.06$ wt $\%$ and 43.50-44.77 wt\% for Khzama, South Aït Ahmane and North Aït Ahmane, respectively, Fig. 10d).
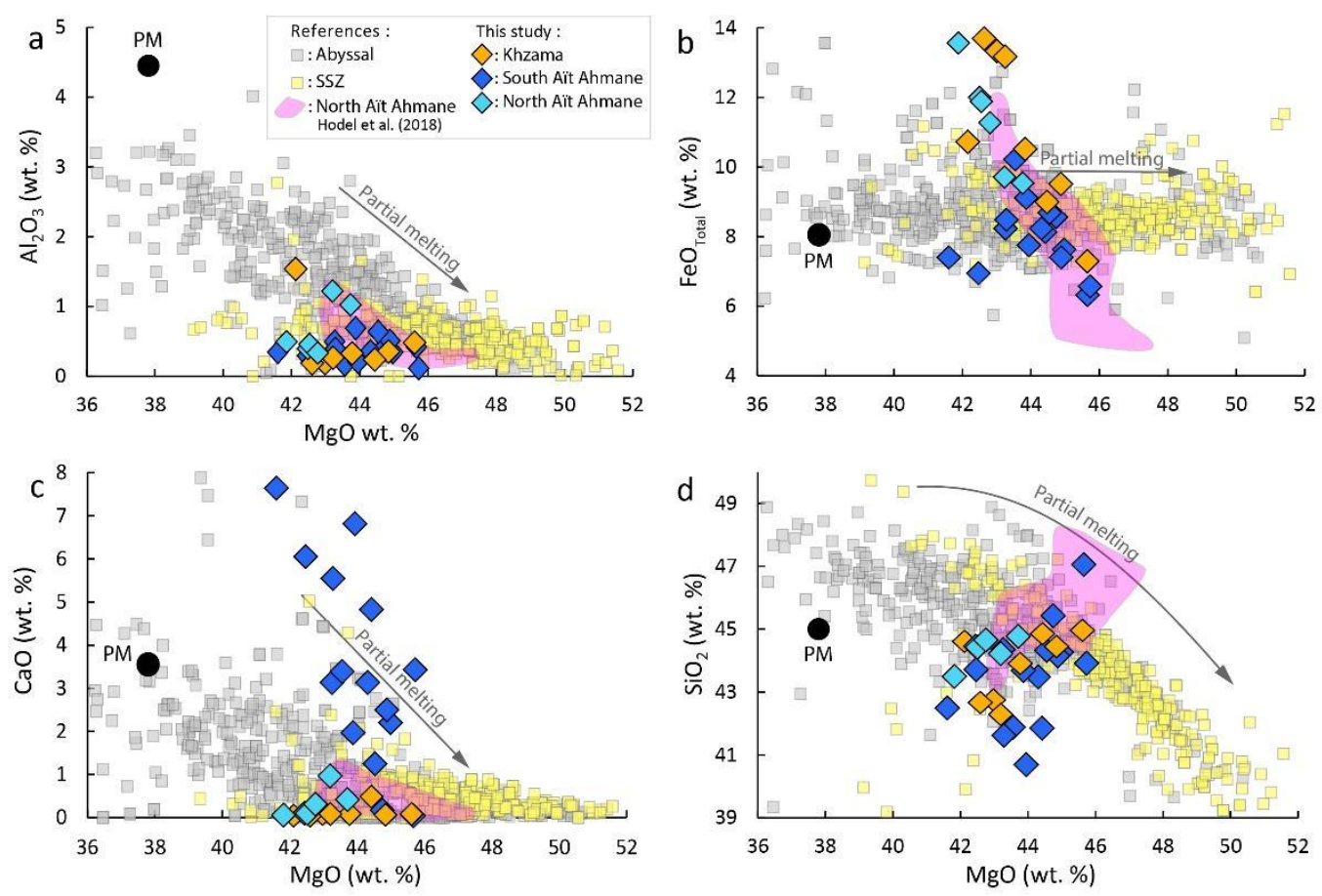

Figure 10: Bulk-rock major oxides contents vs. MgO content (wt\%) diagrams for the Khzama and Ait Ahmane (South and North) serpentinites. Element concentrations are recalculated on a LOI-free basis. (a) Al2O3 vs. MgO; (b) FeO vs. MgO, (c) $\mathrm{CaO}$ vs. $\mathrm{MgO}$ and (d) $\mathrm{SiO} 2$ vs. $\mathrm{MgO}$ contents. The pink domain corresponds to the North Ait Ahmane variously hydrothermalized serpentinites of the Hodel et al. (2018) study. Data for abyssal peridotites are from Snow and Dick (1995), Casey (1997), Niu (2004), Paulick et al. (2006), Godard et al. (2008), Augustin et al. (2012), Boschi et al. (2013), Andreani et al. (2014), Chen et al. (2015). Data for SSZ peridotites are from Ishii et al. (1992), Parkinson and Pearce (1998), Pearce et al. (2000), Savov et al. (2005, 2007), Marchesi et al. (2006, 2009), Kodolányi et al. (2012). Primitive Mantle (PM) values are from McDonough and Sun (1995).

Trace element. Serpentinites from the three units display low to very low incompatible element concentrations such as Ti (3.52 to 64.25 ppm; Fig. 11a), REE (rare earth element, 
$\Sigma$ REE ranging from 0.045 to $1.38 \mathrm{ppm}$ and $\mathrm{Yb}$ from 0.006 to $0.041 \mathrm{ppm}$, Figs. $11 \mathrm{~b}$ and 12 ) and HFSE (e.g. Nb: 0.004-0.099 ppm, Fig. 11).

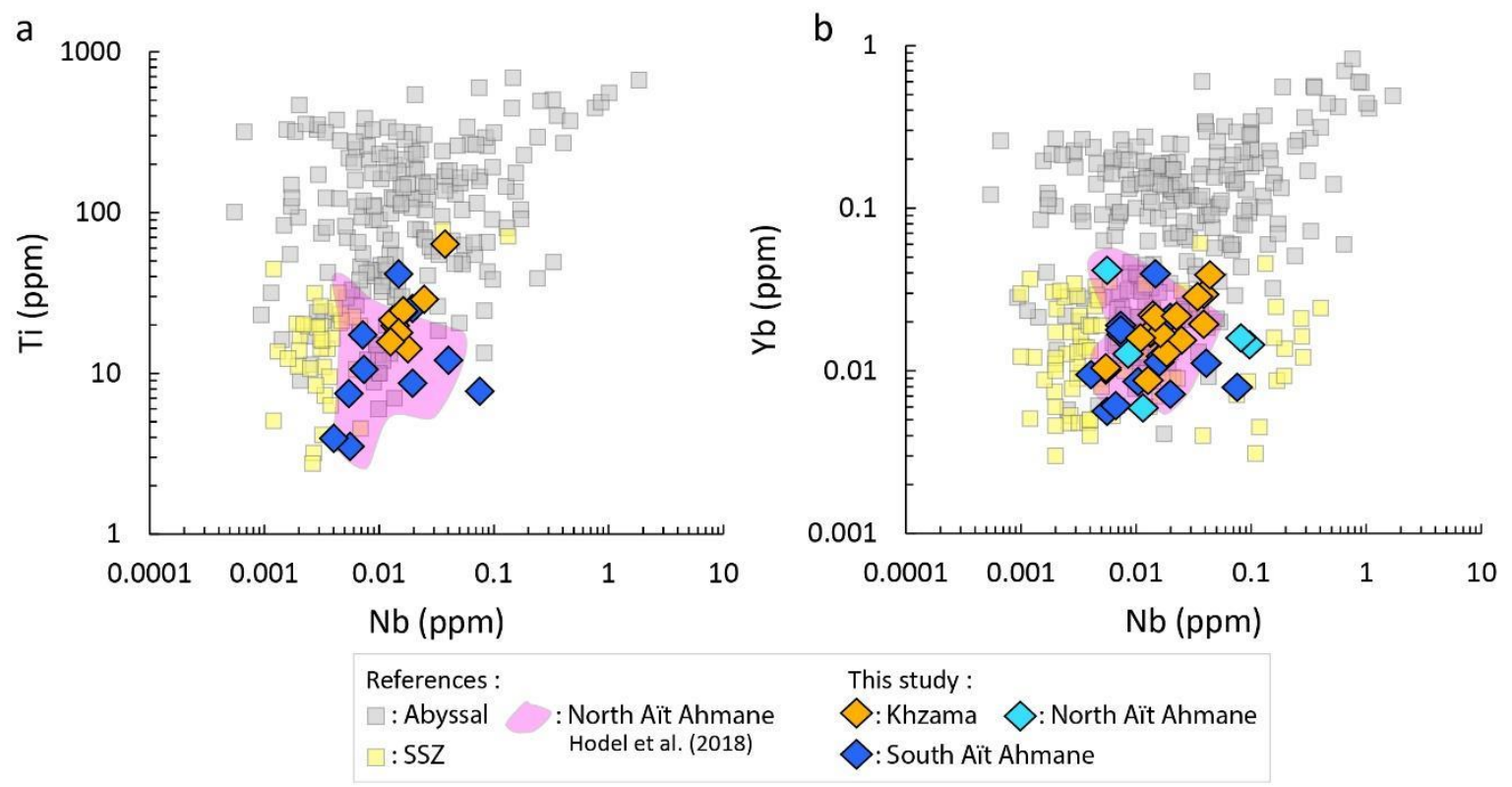

Figure 11: Plot of the whole-rock (a) Ti vs. Nb and (b) Yb vs. Nb contents for the Khzama and Ahmane serpentinites. The pink domain corresponds to the North Ait Ahmane variously hydrothermalized serpentinites of the Hodel et al. (2018) study. References for the compiled data from abyssal and SSZ peridotites and serpentinites are the same as for the Figure 10.

The serpentinites of the Khzama ophiolitic complex exhibit very low concentrations of incompatible trace elements (e.g., Ti: $14.34-64.25 \mathrm{ppm}$ and $\mathrm{Nb}$ : 0.005-0.044 ppm and $\mathrm{Yb}$ : 0.009-0.039 ppm, Fig. 11). They are characterized by low REE contents ( $\Sigma$ REE ranging from 0.178 to $0.686 \mathrm{ppm}$, Fig. 12a) and slightly concave, U-shaped, REE pattern, showing slightly higher LREE (light rare earth elements) and HREE (heavy rare earth elements) compared to MREE (medium rare earth elements) (Fig. 12a). A slight positive anomaly in $\mathrm{Eu}(\mathrm{Eu} / \mathrm{Eu} *=$ 1.13-7.22 times the chondrite) is generally observed for these serpentinites (Fig. 12a). Extended trace element concentrations normalized to the primitive mantle reveal a very weak fractionation between LREE and HFSE, i.e. concentrations of HFSE (high field strength elements, $\mathrm{Nb}, \mathrm{Ta}, \mathrm{Zr}$, Hf) are close to those of the neighboring REEs ( $\mathrm{La} / \mathrm{Nb}$ and $\mathrm{Nd} / \mathrm{Zr}$, respectively between 1.08-18.64 and 0.43-6.43 times the values of the primitive mantle (Fig. 12b). Multi-elemental spidergrams are rather flat, besides a strong positive anomaly in $\mathrm{Pb}$ 
$(\mathrm{Pb} / \mathrm{Ce}$ ratio between 6.80 and $7290 \times \mathrm{PM})$ and another one, more variable and moderate, in $\mathrm{U}$ (U/Th between 2.77 and 157 x PM, Fig. 12b).

The serpentinites of the South Aït Ahmane Unit are characterized by very low contents in incompatible trace elements (e.g., Ti: 3.52-41.70 ppm, Nb: 0.004-0.077 ppm and Yb: 0.006$0.040 \mathrm{ppm}$, Fig. 11) similar to the Khzama serpentinites. They show low and more variable REE concentrations relative to the Khzama ones $(\Sigma \mathrm{REE}=0.045-0.693 \mathrm{ppm}$, Fig. 12c). They also present slightly concave (U-shaped) REE spectra, except for one sample showing important L-MREE enrichment and for two others showing important LREE and variable Eu enrichments (Fig. 12c), similar to these reported by Hodel et al. (2018) for hydrothermalized serpentinites from the North unit. Apart from these two last samples, extended trace element concentrations normalized to the primitive mantle reveal a very weak fractionation between LREE and HSFE (Figs. 12d and 14), as evidenced by the low $\mathrm{La} / \mathrm{Nb}$ and $\mathrm{Nd} / \mathrm{Zr}$ ratios, respectively comprised between 0.64-6.33 and 0.85-16.78 x PM (Fig. 12d). Samples AH03 and L53 with marked LREE enrichments show $\mathrm{La} / \mathrm{Nb}$ and $\mathrm{Nd} / \mathrm{Zr}$ ratios of 26.46 and $13.07 \mathrm{x}$ PM and of 21.4 and $22.4 \times$ PM, respectively. Similar to the Khzama serpentinites, the South Ait Ahmane serpentinites are notably enriched in $\mathrm{Ba}(\mathrm{Ba} / \mathrm{Th}$ ratios between 12.34 and $446 \mathrm{x}$ $\mathrm{PM})$, in $\mathrm{U}(\mathrm{U} / \mathrm{Th}$ between 1.92 and $516 \mathrm{x} \mathrm{PM})$, in $\mathrm{Pb}(\mathrm{Pb} / \mathrm{Ce}$ ratio between 56.93 and $3637 \mathrm{x}$ PM) (Fig. 12d). These samples also display a marked positive anomaly in $\mathrm{Sr}$ ( $\mathrm{Sr} / \mathrm{Nd}$ ratio between 0.59 and $121 \times$ PM; Fig. 12d). 

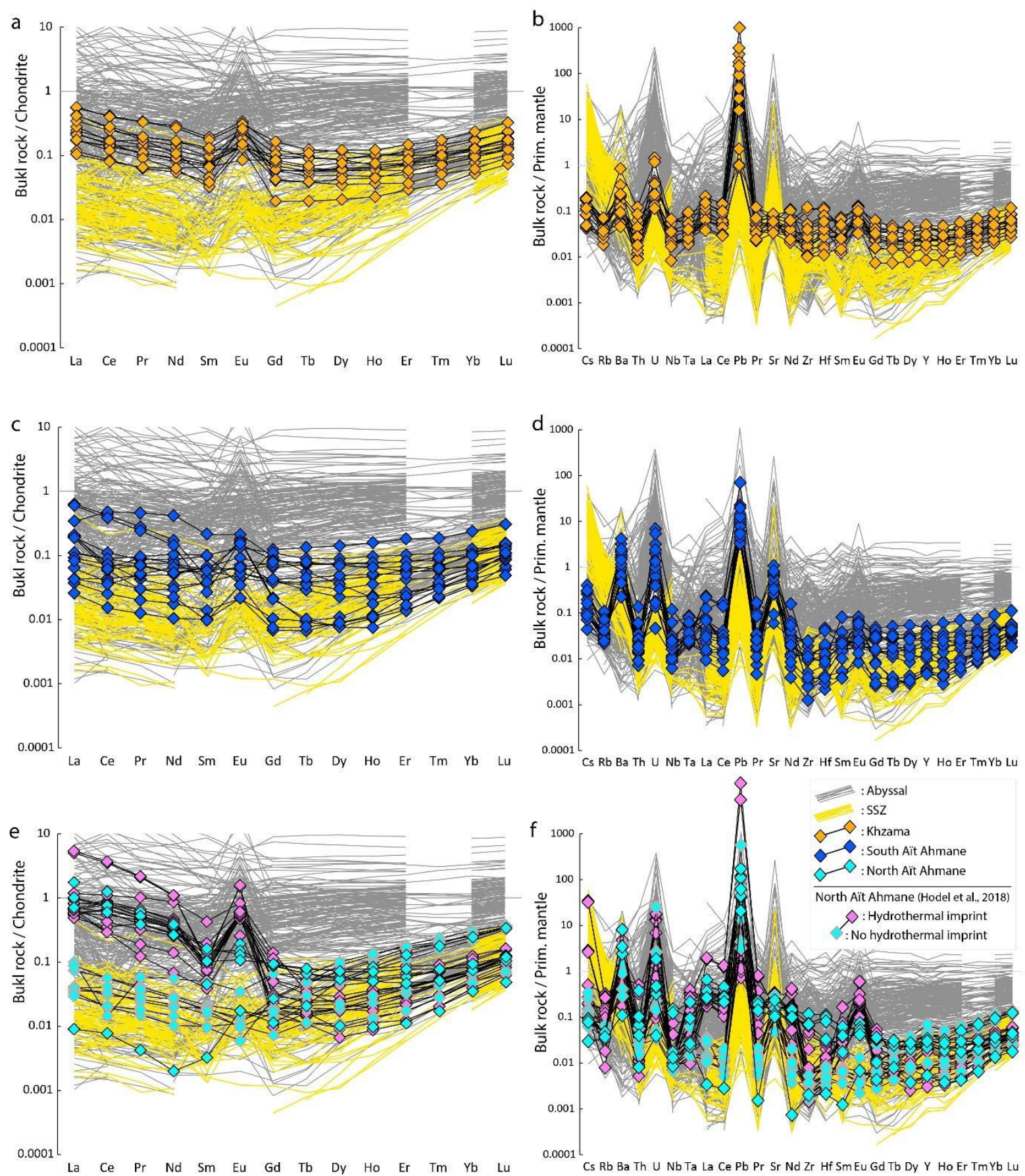

Figure 12: $(a, c, e)$ Chondrite-normalized REE patterns of the Khzama and of the Ait Ahmane serpentinites. Chondrite values are from Barrat et al. (2012). (b, $d, f)$ Primitive mantle-normalized multi-element patterns of the Khzama and the Ait Ahmane serpentinites. Primitive mantle values are from McDonough and Sun (1995). Data for abyssal peridotites and serpentinites are from Niu (2004), Paulick et al. (2006), Godard et al. (2008), Augustin et al. (2012), Boschi et al. (2013), Andreani et al. (2014), Chen et al. (2015). Data for SSZ peridotites and serpentinites are from Parkinson and Pearce (1998), Pearce et al. (2000), Savov et al. $(2005,2007)$ and Kodolányi et al. (2012). 
The samples collected in the North Aït Ahmane unit attest of the geochemical heterogeneity of the serpentinites from this unit. They are also characterized by low to very low incompatible trace elements contents (e.g. Nb: 0.006-0.099 ppm and Yb: 0.006-0.041 ppm, Fig. 11) and variable REE contents ( $\mathrm{REE}=0.11-1.38 \mathrm{ppm}$, Fig. 12e). Based on HREE, we distinguish two types of serpentinite protolith, also noticeable in the previous sampling of Hodel et al. (2018) (Fig. 12e): (1) concave patterns and very low HREE contents and (2) convex patterns showing higher HREE concentrations. Based on LREE patterns, several subsets are identified (Fig 11e): Sample L37 display a strongly LREE-depleted spoon-shaped REE pattern $(\Sigma \mathrm{REE}=0.11 \mathrm{ppm}$, Fig. 12c), with convex HREE pattern similar to those noticed above. Inversely, sample L34A shows the same REE element pattern than the serpentinites belonging to the nearby fossil hydrothermal system described by Hodel et al. (2018), i.e. a strong LREE enrichment ( $\mathrm{La} / \mathrm{Yb}$ ratio of 50.87 times the chondrite) and a marked positive $\mathrm{Eu}$ anomaly $\left(\mathrm{Eu} / \mathrm{Eu}^{*}=5.38\right.$ times the chondrite) (Fig. 12e). For this sample, high $\mathrm{La} / \mathrm{Nb}$ of 37.44 times the primitive mantle values suggest that hydrothermal processes likely led to amagmatic LREE enrichment (e.g., Hodel el al., 2018, Fig. 12f, see further discussion). Finally, the samples L32, L34B and L36 display important enrichments in LMREE and flatter REE patterns (Fig. 12f).

\section{In situ U-Pb dating}

Zircons and apatites were extracted from the metagabbroic unit of the Northern Ait Ahmane ophiolitic unit (sample L72: UTM29N-WGS84: X 731998 m - Y 3373222 m). Sample L72 consists of a layered metagabbro exposed as a pluri-metric tectonic slice intercalated within the serpentinite units (see location on Fig. 2b). It is part of the type 1, N-MORB-like metagabbro previously described (see Fig. 8). Zircon and apatite crystals were extracted via heavy liquid (Methylene Iodide), magnetic separation and manual hand-picking. Optical cathodoluminescence images (CL, see Appendix A1 for imaging conditions) were captured to 
select the location of the spots for LA-ICP-MS analyses (see Appendix A1 for analytical methods and procedure). The full U-Pb isotopic dataset and calculated ages can be found in Supplementary material 6. Concordia diagrams and calculated ages have been produced using IsoplotR (Vermeesch, 2018).

\subsection{Zircon $\mathrm{U}-\mathrm{Pb}$ age}

Zircon grains are 50 to $120 \mu \mathrm{m}$ long, prismatic and colorless showing euhedral to subhedral shape with rounded edges. They are relatively homogeneous in terms of luminescence. They show occasional oscillatory zoning (Fig. 13b) suggesting magmatic crystallization (Corfu et al., 2003). They do not show any evidence for inheritance from older cores. This magmatic origin is confirmed by the high $\mathrm{Th} / \mathrm{U}$ ratios with an average value of 0.23 in contrast with low Th/U ratios attributed to metamorphic zircons (e.g., Hoskin and Schaltegger, 2003). Their general low contents in $\mathrm{U}$ and $\mathrm{Th}$ (hence, $\mathrm{Pb}$ ) are consistent with crystallization in a mafic magma (Kydonakis et al., 2014). The isotopic data plot in a concordant to discordant position in a Tera-Wasserburg concordia diagram (Fig. 13a), due to the presence of variable amounts of common $\mathrm{Pb}$ within the zircon grains. They define a lower intercept date of $745.9 \pm 7.4 \mathrm{Ma}$ (MSWD=1.3, $\mathrm{n}=32$ ). We refined these data by selecting $\mathrm{U}-\mathrm{Pb}$ analyses showing more $95 \%$ of concordance $(n=15)$. Plotted in a Wetherill Concordia diagram, these data yield a wellconstrained concordant age of $758.7 \pm 2.1 \mathrm{Ma}(\mathrm{MSWD}=0.75)$.

\subsection{Apatite U-Pb age}

Apatites are 40 to $90 \mu \mathrm{m}$ long and colorless showing subhedral shape with rounded edges. They show a homogeneous luminescence pattern (Fig. 13d). Under the microscope, apatite typically occurs at grain joints between amphibole and plagioclase (Fig. 3a). The 2-sigma ellipses are widely spread $(\mathrm{MSWD}=3, \mathrm{n}=30$, Fig. 13c). Uncorrected isotopic data are aligned in Tera-Wasserburg diagram yielding a lower intercept date of $659 \pm 7 \mathrm{Ma}$ (Fig. 13c). 

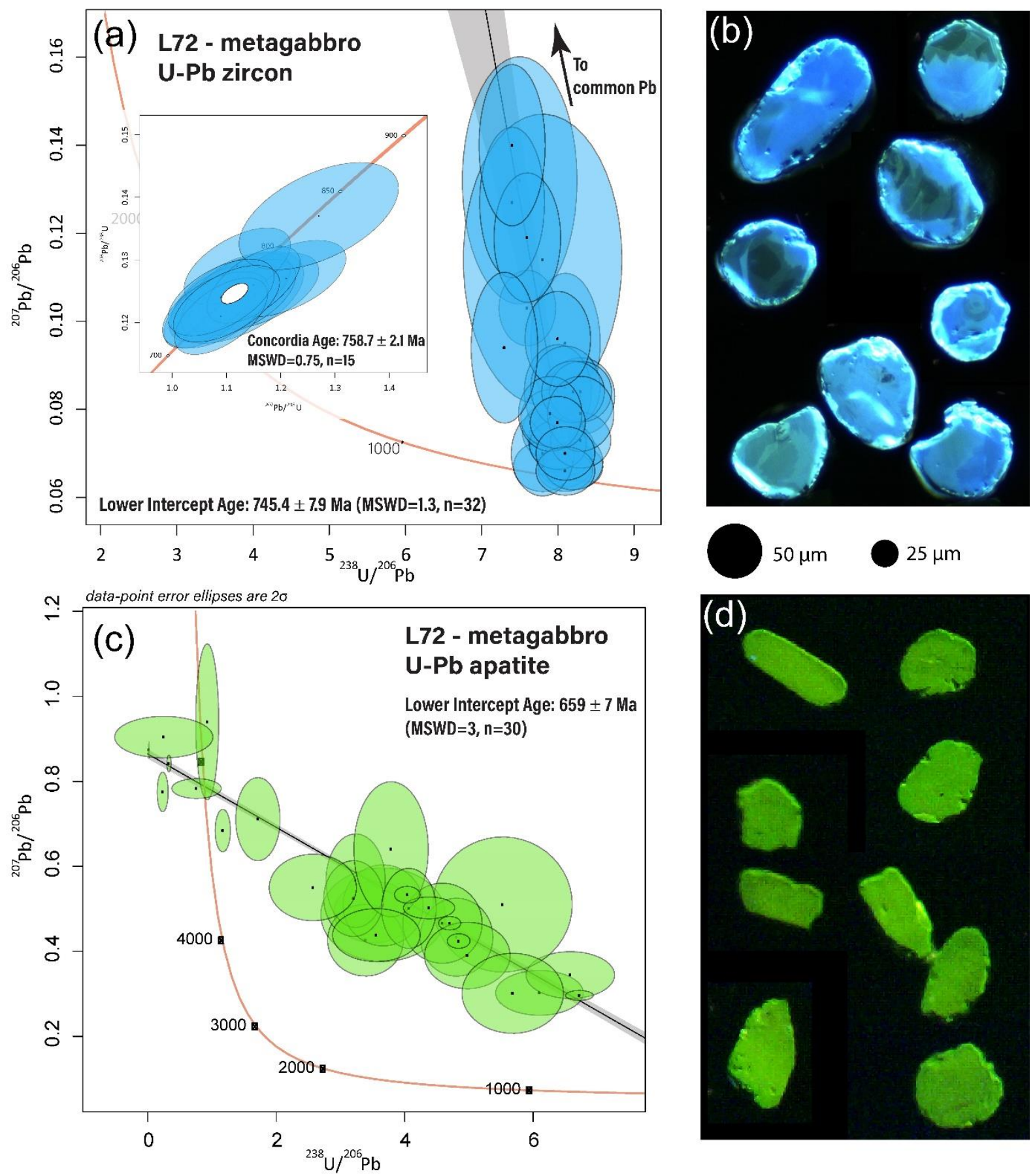

Figure 13: (a) Tera-Wasserburg and Wetherill Concordia (embedded) U-Pb diagram for zircons extracted from L72 metagabbro. The latter yields a concordant age at $758.7 \pm 2.1 \mathrm{Ma}(\mathrm{MSWD}=0.75)$. (b) Optical CL (cathodoluminescence) microphotographs of analyzed zircons. (c) Tera-Wasserburg U-Pb diagram for apatites extracted from L72 metagabbro. Lower intercept yields an age at $659 \pm 7 \mathrm{Ma}(M S W D=3)$. (d) Optical CL microphotographs of the analyzed apatite grains. 


\section{Discussion}

\subsection{Regional significance of the Aït Ahmane ophiolite U-Pb zircon and apatite ages}

The age of the Anti-Atlas ophiolitic complexes and by extension, of the Neoproterozoic oceanic spreading that precedes the Pan-African orogeny in the Anti-Atlas, has been debated in the past. The Sirwa ophiolite has been dated at $762 \pm 2 \mathrm{Ma}$ using U-Pb method on zircon grains from a plagiogranite (Samson et al. 2004). Concerning the Bou Azzer ophiolite, the first proposed age for the oceanic crust was determined ca. $788 \pm 10 \mathrm{Ma}$ (Clauer, 1976) using $\mathrm{Rb}-\mathrm{Sr}$ method on sedimentary sequence in direct contact with intrusive mafic rocks from the ophiolitic sequence, and therefore, interpreted as metamorphic age due to the emplacement of the mafic magmatic rocks. El Hadi et al. (2010) dated metagabbroic units at $697 \pm 8 \mathrm{Ma}$ (U$\mathrm{Pb}$ on zircons) and interpreted this date as the age of the Bou Azzer ophiolite. These ones are exposed in the Bougmane complex located to the southern part of the Bou Azzer inlier and disconnected from the ophiolitic units. Moreover, Triantafyllou et al. (2018) dated similar metagabbroic rock associated to mafic granulite in the Bougmane complex at $706 \pm 9 \mathrm{Ma}$. These authors showed that they were formed in the lower crust of a thick oceanic arc and that they are consequently not directly related to the evolution of the SSZ spreading system. Hence, this metagabbroic rock do not belong the Bou Azzer ophiolite.

Our study provides an $\mathrm{U}-\mathrm{Pb}$ age for the Ait Ahmane sequence obtained on zircon from a layered metagabbro, which provides an age at $759 \pm 2 \mathrm{Ma}$ (Fig. 13a). This metagabbro is part of the ophiolitic sequence (Fig. 2b) as attested by its NMORB chemical signature (also showing LILE enrichment, Fig. 8), its structural position between metabasalts and serpentinites and the absence of granulite-grade recrystallization. We interpret this date as the crystallization age for this metagabbro protolith. This new age is in agreement with previous 
$\mathrm{Rb}-\mathrm{Sr}$ dating (Clauer, 1976). It thus constitutes the best estimate of the age of the Bou Azzer ophiolite.

Our study also provides a U-Pb date of $659 \pm 7 \mathrm{Ma}$ for apatite grains extracted from the same layered metagabbro (sample L72, Fig 13c). As apatite closure temperature for Pb diffusion is low $\left(375-550^{\circ} \mathrm{C}\right), \mathrm{U}-\mathrm{Pb}$ ages from apatite can be interpreted as cooling ages and/or resetting during a thermal event (e.g. Cherniak et al., 1991; Chamberlain and Bowring, 2001; Schoene and Bowring, 2007; Cochrane et al., 2014). Hence, this age could be interpreted: (i) as a reset of the $\mathrm{U}-\mathrm{Pb}$ isotopic chronometer during the 650-660 Ma arc magmatic pulse marked in the area by the emplacement of numerous dioritic intrusions within the ophiolitic sequence; or (ii) as the early retrograde stage following the amphibolitisation of these ophiolitic gabbroic units. 659 Ma closely corresponding to the age of intrusive diorites into the Bou Azzer ophiolitic sequence, we suggest that this age represents thermal resetting of the apatite in the metagabbro during the last magmatic pulse affecting the Anti-Atlasic supra-subduction system (Triantafyllou et al., 2020).

These new ages suggest that both Bou Azzer and Sirwa ophiolites were formed during the same oceanic spreading event between 760 and $730 \mathrm{Ma}$, concurrently with the first built-up stage of an intra-oceanic arc recorded in Tachakoucht, Tazigzaout, Bougmane complexes (with oldest magmatic ages constrained at $743 \mathrm{Ma}, 753 \mathrm{Ma}$ and $755 \mathrm{Ma}$; e.g. Thomas et al., 2002; D'Lemos et al., 2006; Admou et al., 2013).

\subsection{Magma heterogeneities representative of back-arc magmatism}

After describing the Bou Azzer (Leblanc, 1975) and the Sirwa (Chabane, 1991) sequences as oceanic lithosphere remnants, previous studies suggested on the basis of the composition of mafic lavas that these ophiolitic sequences were related to the Anti-Atlasic subduction zone bordering the WAC and associated volcanic arcs (e.g., Naidoo et al., 1991; Bodinier et al., 
1984; Triantafyllou et al., 2016, 2018, 2020). Field observations and magnetic geophysical survey (Soulaimani et al., 2006; Hefferan et al., 2014; Triantafyllou et al., 2016, 2018, 2020) demonstrated that the main structures accommodating the Cryogenian ophiolite and arc accretions are dipping to the north with a southward vergence. Accordingly, from a geometrical point of view, the arc complexes being located to the south of the dismembered ophiolite, the latter consequently represents the back-arc domain (Fig. 2a, b). In parallel, forearc basalt such as those from the Izu-Bonin system are extremely homogeneous, depleted in incompatible trace-elements compared to MORBs and are characterized by very low $\mathrm{Th} / \mathrm{Yb}$ and $\mathrm{Nb} / \mathrm{Yb}$ ratios (Reagan et al., 2010; Hickey-Vargars et al., 2018). They usually alternate with boninitic lavas having basic to intermediate $\mathrm{SiO}_{2}$ contents (typically 50-60 wt.\%) with elevated $\mathrm{MgO}$ (>10 wt\%) (Reagan et al., 2017; Woelki et al., 2018). Such geochemical signatures have not been found in the Anti-Atlas ophiolites, supporting the idea that they originate from a back-arc setting.

As a whole, the geochemical signatures of mafic rocks from the Aï Ahmane and Khzama ophiolitic sequences are heterogeneous, in line with the magma heterogeneity that characterize back-arc environments (e.g., Shinjo et al., 1999; Taylor and Martinez, 2003; Pearce et al., 2005; Tian et al., 2008; Bézos et al., 2009). Indeed, geochemical heterogeneity is one the hallmarks of BABB (Back-Arc Basin Basalts) due to their inherited MOR-like signature coupled with variable amount of subduction component imprint (e.g. Pearce et al., 2005; Pearce \& Stern 2006). The parental magmas of metabasalts from the Anti-Atlas ophiolites appear to have been variously impacted by subduction related processes. They show geochemical signatures ranging from LREE depleted to LREE enriched composition, which are always accompanied by a negative $\mathrm{Nb}$ anomaly (Fig. 6). They also display various incompatible element abundances such as $\mathrm{Ti}$ and $\mathrm{Zr}(\mathrm{Ti} / \mathrm{Yb}$ and $\mathrm{Zr} / \mathrm{Yb}$ ranging from 12084227 and 11-56 respectively), which when high fall in the MORB array and when low sign a 
SSZ setting (Fig. 7b, c). Finally, they also show LILE enrichments (Fig. 6) and high and variable $\mathrm{Th} / \mathrm{Yb}$ ratios $(0.06-1.07)$ for quite low $\mathrm{Nb} / \mathrm{Yb}(0.60-3.41)$ compared to MORBs, reflecting that up to $4 \%$ of a slab-derived component enriched their mantle source (Fig. 7). Regarding metagabbros, in Aït Ahmane, some trace-element rich metagabbros display NMORB fingerprints similar to upper crust gabbroic rocks of the Samail ophiolite, while others are much more depleted similarly to lower gabbros of the Samail ophiolite (Fig. 8). This likely reflects magmatic differentiation processes. These metagabbros can therefore derive similarly from upper and lower crust section in Ait Ahmane. In either case, they are characterized by low $\mathrm{Th} / \mathrm{Yb}$ ratios (0.01-0.04), which suggest a depleted mantle decompression melting without major subduction component. Such MORB-like magmas devoid of $\mathrm{Nb}-\mathrm{Ta}$ anomalies, i.e. not influenced by subduction components, are common in back-arc domains worldwide (Taylor and Martinez, 2003; Pearce et al., 2005).

Hence, this geochemical heterogeneity of mafic lithologies and the association of both MORB-like and subduction related melts tend to confirm that the Khzama and Aït Ahmane oceanic lithosphere were formed in a back-arc environment (e.g. Shinjo et al., 1999; Taylor and Martinez, 2003; Pearce et al., 2005; Tian et al., 2008).

\subsection{Origin of the variably depleted signature of the Anti-Atlas serpentinites}

Ultramafic units of the Moroccan Anti-Atlas ophiolites remain poorly constrained in terms of geochemistry. Through this study, we challenged to study the geochemical signature of serpentinites in order to decipher their primary chemical signal, and thus to constrain the magmatic history of these mantle rocks.

\subsubsection{Serpentinization imprint and exclusion of hydrothermalized samples}


Given this petrogenetic purpose, a sorting was necessary to dissociate magmatic vs. hydrothermal geochemical imprints in order to discard samples for which pristine magmatic signature is not well preserved.

It has been shown that LREE and, in a lesser extent, MREE (particularly Eu) can be strongly affected - enriched relatively to HREE - by hydrothermal processes involving hot acidic fluids, as those encountered in black smoker type hydrothermal systems for instance (e.g. Paulick et al., 2006; Craddock et al., 2010, Andreani et al., 2014; Hodel et al., 2018). However, LREE and MREE enrichments in depleted ultramafic rocks also often result of melt-rock reaction or refertilization processes before serpentinization (e.g. Navon and Stolper, 1987; Vernières et al., 1997; Godard et al., 2000, 2008; Bodinier and Godard, 2003; Saka et al., 2014; Warren, 2016). A relevant way to discriminate a magmatic or hydrothermal origin for L-MREE enrichments in serpentinized peridotites is to consider their HFSE contents. Indeed, these latter are not - or very slightly - mobilized during serpentinization and hydrothermal processes (You et al., 1996; Kogiso et al., 1997; Niu, 2004; Paulick et al., 2006; Deschamps et al., 2013). Thus an important fractionation between LREE and HFSE signs a hydrothermal (i.e. aqueous) imprint, while unfractionated HFSE and LREE contents reflect magmatic processes involvement (e.g. Niu, 2004; Paulick et al., 2006, Hodel et al., 2018; Fig. 14).

Hodel et al. (2018) previously shown that most of the serpentinites of the North Aït Ahmane unit displayed important LREE enrichments and strong LREE vs. HFSE fractionation (Figs. 12 and 14), as a result of intense hydrothermal alteration. Two other serpentinite samples from the North Aït Ahmane unit (samples L34A and L36) display similar geochemical signature, attesting a potential link with this episode. Other serpentinites from the South Aït Ahmane unit (samples AH01B, AH03, L50 and L53) and from the Khzama unit (sample SH09 and KK14A) also show LREE enrichments and important LREE vs. HFSE fractionation 
reflecting a probable hydrothermal origin for these signatures as well (Fig. 14). Setting aside these samples, L-MREE enrichments noticed for most of the Khzama and the Aït Ahmane serpentinites studied here (U-shaped REE patterns, Fig. 12a, c, e) are almost always accompanied by HFSE enrichment testifying of their magmatic origin (Figs. 12 and 14). We therefore excluded all the samples showing hydrothermal geochemical imprint of our following magmatic investigations (samples L34A, L36, AH01B, AH03, L50, L53, SH09 and KK14A).

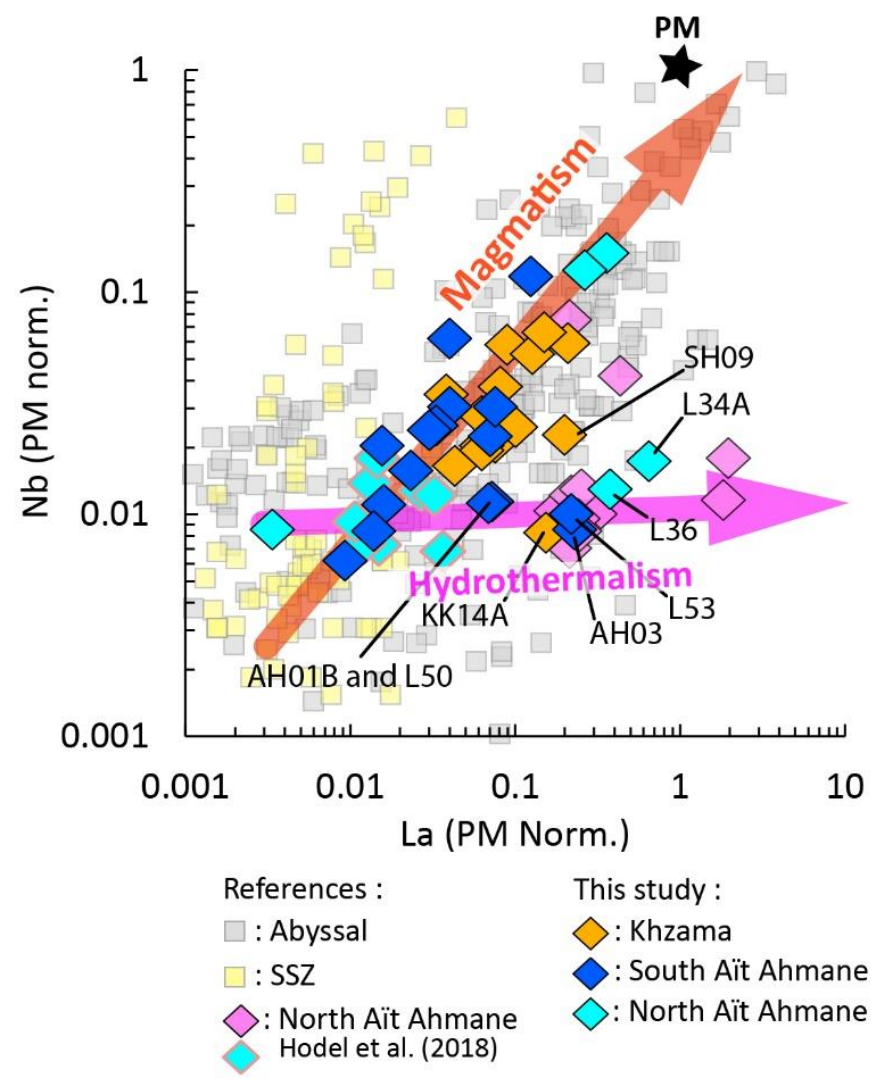

Figure 14: Primitive Mantle (PM) normalized Nb vs La contents of the Khzama and the Ait Ahmane serpentinites allowing to decipher between hydrothermal and magmatic processes to explain LREE enrichments in most of the serpentinites from the three units (U-shaped REE patterns, Fig. 12a, c, e). Legend for the North Ait Ahmane serpentinites analyzed by Hodel et al. (2018) is the same as in Figure 12. Primitive mantle values are from McDonough and Sun (1995). Compilation used for abyssal and SSZ peridotites and serpentinites is the same as for previous figures.

7.2.2 Multiple stages of mantle partial melting and liquid extraction 
Both Khzama and Aït Ahmane serpentinites show very low $\mathrm{Al}_{2} \mathrm{O}_{3}$ contents (Figs. 9 and 10), together with intermediate to high spinels' $\mathrm{Cr} \#$ and low to high $\mathrm{Mg \#}$ ratios (Fig. 5a) suggesting a highly depleted ultramafic protolith. These proxies attest of a partial melting ranging from $25 \%$ to more than $35 \%$ for the precursor of the Khzama and Aït Ahmane serpentinites (Fig. 5a). Such extreme melting degrees are not compatible with MOR-like dry decompression melting (e.g., Dick and Bullen, 1984; Ishii et al., 1992; Arai, 1994; Warren, 2016). They are nowadays considered as being one of the hallmarks of the supra-subduction environments, where peridotites experience intense and/or multiple flux melting episodes (Bizimis et al., 2000, Barth et al., 2008, Ulrich et al., 2010, Uysal et al., 2012, 2016). Low incompatible trace elements ( $\mathrm{Ti}, \mathrm{Nd}$ and $\mathrm{Yb}$ ) and REE contents also fit with these commonly reported for SSZ fresh and serpentinized peridotites (Figs. 11 and 12).

To better constrain partial melting and fluid-melt-rock interaction processes, we performed partial melting modeling using REE compositions of the serpentinites via closed- and opendynamic melting reactions (see equilibrium equations reviewed in Zou, 2007) (Fig. 15). These melting models are non-modal dynamic melting. Porosity value $(\varphi)$ has been set to $1 \%$ and corresponds to the proportion of melt trapped in the residue composition (e.g. Uysal et al., 2012). Starting mantle composition is DMM (Depleted MORB Mantle; after Workman and Hart, 2005), which reproduces typical compositional range of depleted peridotite composition formed in abyssal context (see Fig. 11 in the review paper of Warren et al., 2016) after 1017\% of partial melting of non-depleted Primitive Mantle (PM) (e.g., Uysal et al., 2016; Hao et al., 2016). Models' parameters and partition coefficients are presented in Supplementary material 7.

Here we used HREE ( $\mathrm{Yb}, \mathrm{Lu})$ concentrations to constrain partial melting degree for the studied serpentinites; MREE and LREE being strongly affected by metasomatism and magmatic refertilization processes (modal and cryptic, Navon and Stolper, 1987; Godard et 
al., 1995; Vernières et al., 1997; Warren and Shimizu, 2010). Based on HREE abundances, two groups have therefore been identified (group A and group B, respectively marked by high and low HREE; Fig. 15). Group A serpentinites result of F: $15 \%$ partial melting in a closed dynamic model (see gray lines in Fig. 15a) while group B serpentinites are residues after higher partial melting degree (F: 18-19\%; Fig. 15b, c). The group B could be divided in two subgroups, B1 and B2, based on HREE contents. Group B1 REE patterns are well clustered, while HREE from B2 group serpentinites show more spread values, probably due to the slight influence of melt-rock interaction discussed in the next section.

This variability in partial melting degree along with the highly depleted character of the Khzama and Aït Ahmane serpentinites attests of their complex magmatic history. They both suggest that these residues were affected by at least two partial melting events. For both scenarios, high degrees of partial melting (sum of $\mathrm{F}$ of two melting episodes ranging between: 20 and 33\%) are in agreement with those recorded by spinel composition (Fig. 5) and major elements bulk-rock composition (Figs. 9 and 10). 

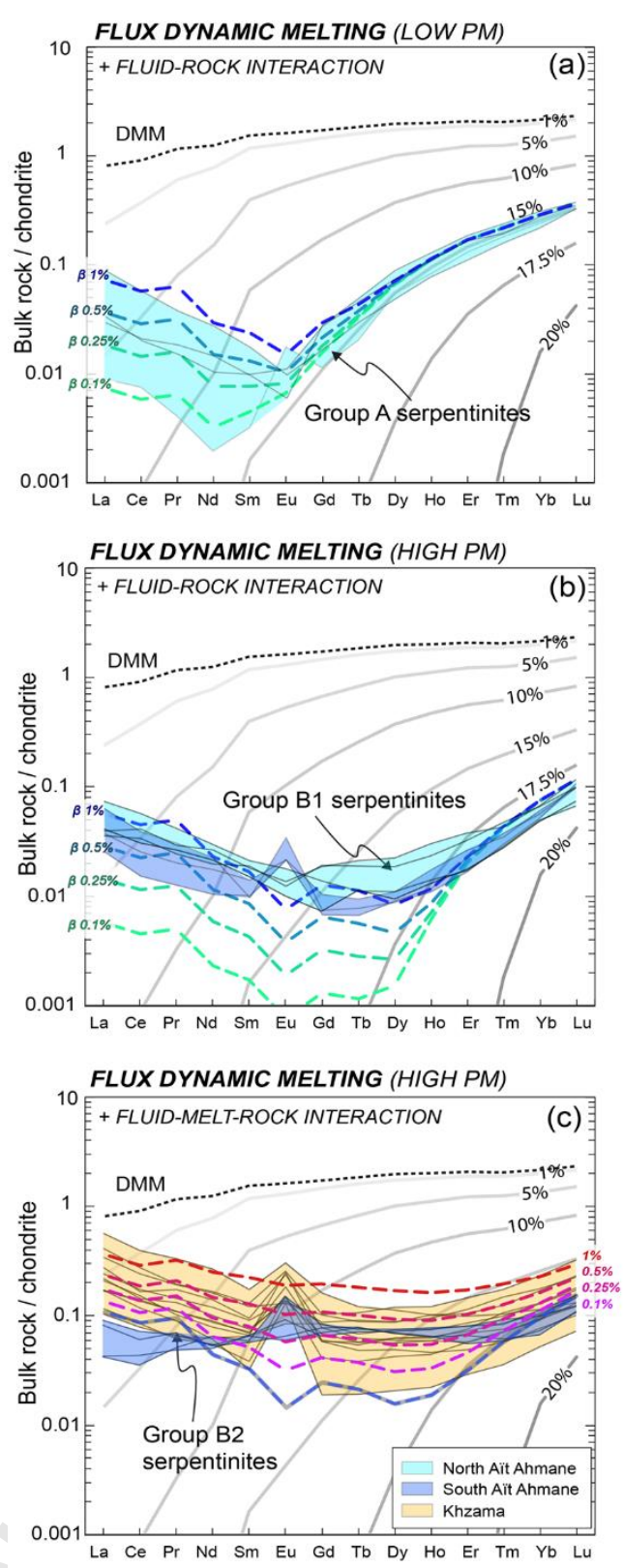

Figure 15: Closed- and open-dynamic melting model of a Depleted MORB Mantle (DMM) protolith. Modeled patterns are compared to REE composition of Ait Ahmane and Khzama serpentinites. Black dashed line is for DMM starting composition (after Workman and Hart, 2005). Grey lines in (a), (b) and (c) are for closed-system non-modal dynamic melting (porosity $\varphi=$ 1\%). Green to blue lines in (a) and (b) are for open-system non-modal dynamic melting ( $\varphi=1 \%$ and SSZ-fluid influx $\beta$ from 0.1 to $1 \%$ after Eiler et al., 2000; 2007). Pink to red lines in (c) are for melt-rock mixing model between a flux molten residue and an IAB (X from 0.1 to 1\%). See sections 7.2.2 and 7.2.3 and Supplementary material 7 for more details about the model's parameters.

\subsubsection{Interaction between SSZ fluid-melt-mantle rocks}


Most of the studied serpentinites show enrichments in LREE and/or in MREE contents that are not predicted by classic closed system melting models (Vernières et al., 1997; Godard et al., 2000, 2008; Bodinier and Godard, 2003 and see gray lines in Fig. 15). LREE-MREE enrichments producing the U-shaped REE patterns of the Khzama and the Ait Ahmane being, in most cases, accompanied by HFSE enrichments (Fig. 14), they likely originate from magmatic (refertilization/enrichment) processes in an open system. Similar concave REE patterns are commonly reported for heavily depleted peridotites and ophiolitic serpentinites from subduction contexts and are interpreted as resulting of intense and/or multiple hydrous partial melting associated with refertilization or metasomatic processes involving subduction related LREE-rich melts (Prinzhofer and Allègre, 1985, Gruau et al., 1998, Dubois-Cote et al., 2005, Barth et al. 2008, Ulrich et al., 2010, Uysal et al., 2012, 2015, 2016). In addition, high Ti content (up to $0.26 \mathrm{wt} \% \mathrm{TiO}_{2}$, Fig. 5b) in spinels from the Khzama serpentinite comforts post/syn-melting melt-rock interaction involving melts derived from the subduction system, as commonly observed for peridotites in supra-subduction (SSZ) environment (e.g., Bizimis et al., 2000; Pearce et al., 2000; Ulrich et al., 2010; Uysal et al., 2015, 2016) (Fig. 5b). Such melt/rock interaction processes are also corroborated by the REE patterns of these Khzama serpentinites, which display the strongest LREE-MREE enriched, U-shaped REE patterns (see modeling approach below).

To reproduce LREE and MREE signature, we also performed open-system dynamic melting model with the same parameters described in section 7.2.2. We used DMM as protolithic composition too but using a subduction component (SSZ-fluid gathered and compiled from Eiler et al., 2000; 2007) as influx material quantified by the parameter $\beta$ (expressed in \%; see green to blue lines in figure 15a, b). The group A1 serpentinites (North Aït Ahmane unit only) show a convex HREE pattern and a strong bend of MREE to LREE pattern (centered on Eu; Fig. 15a). This group is well modelled using such a flux dynamic melting (Fig. 15a) with 
melting degree comprises between 15 and $16 \%$ and variable SSZ-fluid influx value $(\beta)$ ranging from 0.1 to $1.0 \%$. The group B1 (North and South Ait Ahmane) and B2 (South Aït Ahmane and Khzama) serpentinites are marked by a smoother and concave HREE pattern resulting from a REE enrichment affecting both L- and MREE (and even HREE for Khzama samples) (Fig. 15c). For the B1 group serpentinites, dynamic melting model predicts a higher partial melting degree ranging from 18 to $19 \%$ and similar influx $\beta$ value of 0.5 to $1.0 \%$. Nonetheless, for some samples, higher content in MREE to HREE (Gd to Er) relative to the fluid-only dynamic model could be better explained by a slight interaction with a melt as shown in Figure 15c. The B2 group serpentinites are well modelled using a flux dynamic melting (Fig. 15c), with high melting degree and moderate proportions of subduction component influx similar to B1 group (F: $19 \%$ and $\beta$ : $0.5-1.0 \%$, see blue dashed line on Fig. $15 \mathrm{c}$ ) subsequently affected by melt-rock interactions with 0.1 to $1.0 \%$ (parameter $\mathrm{X}$ ) of percolating arc-related basalts (see pink to red dashed lines on Fig. 15c; we here used a median of IAB gathered from PetDB; in Supplementary material 7). We also compared with averaged boninitic and $\mathrm{BABB}$ available but $\mathrm{IAB}$ composition fit better. Group B2 serpentinites composition could thus be reasonably explained by a combination of subduction influx during the melting event and by subsequent melt-rock interactions with percolating arc related basalts, as recorded by high $\mathrm{Ti}$ contents of the Khzama serpentinites spinels and moderate values for the other serpentinite samples (Fig. 5b).

\subsection{Conclusions}

- Our new geochronological data confirms the petrogenetic link between the Sirwa (762 \pm 2 Ma, Samson et al., 2004) and the Bou Azzer ophiolites (759 \pm 2 Ma, this study). These 
ophiolites probably represent different relics of a same oceanic lithospheric plate, formed synchronously with the first building stage of the Moroccan Anti-Atlas intra-oceanic-arc.

- Considering an ocean-ward subduction geometry, which is nowadays rather consensual, the northern location of the Anti-Atlas ophiolites relative to these arc complexes supports the fact that they formed in a back-arc basin (Fig. 16). The back-arc setting of the three studied ophiolites is also supported by the coexistence of MOR-like and SSZ-related mafic lithologies. Neither boninitic magmatism nor subduction channel melange, nor high to ultrahigh pressure-low-temperature relics (which are common in fore-arc domains) have been described so far in the arc-related units in Sirwa and Bou Azzer inliers, discarding their formation in a fore-arc setting.

- Regarding ultramafic rocks, their very low major and trace incompatible element contents, along with high $\mathrm{Cr} \#$ for low to intermediate $\mathrm{Mg \#}$ in their constitutive $\mathrm{Cr}$-spinel, denote that these rocks endured high partial melting degrees, which are incompatible (or at least, very uncommon) with dry MOR-like melting. These observations combined to REE melting modelling approach reveal that the Khzama and the Aït Ahmane serpentinites precursor experienced a polyphased open-system melting history, strongly influenced by SSZ-fluid influx and subduction-related melts percolations.

- The variability of the geochemical signatures of mantle rocks between the studied ophiolitic units can be used as a tracer of refertilization intensity, and hence as a marker of vicinity to the sub-arc mantle region (e.g. see Tollstrup et al., 2010's equivalent approach for mafic rocks). Here, the Khzama ophiolitic sequence, is highly affected by SSZ metasomatism and IAB percolation as denoted by Ti-enriched spinels and modelled REE patterns. Similar IAB percolation is also characteristic for the South Ait Ahmane unit but is very uncommon in the North Aït Ahmane ones. In addition, both Khzama and South Aït Ahmane units are geometrically closer to their associated arc complexes (Iriri-Tachakoucht and Bougmane complexes, respectively) compared to the North Ait Ahmane unit. All these observations 
argue that both Khzama and South Aï Ahmane units were likely formed synchronously during an early spreading stage in the back-arc region. This scenario predicts that their mantle section would be closer to the sub-arc region where intense arc magma production and slab-derived metasomatism prevail. In turn, the northern Aït Ahmane unit likely formed during a later stage of the back-arc spreading, hence being less affected by slab- and sub-arcderived influxes (Fig. 16.

- Future studies should focus on improving the petrochronological records in each of ophiolitic sequence to testify our geodynamic model and to better constrain the timing and evolution of intra-oceanic arc-back-arc systems.

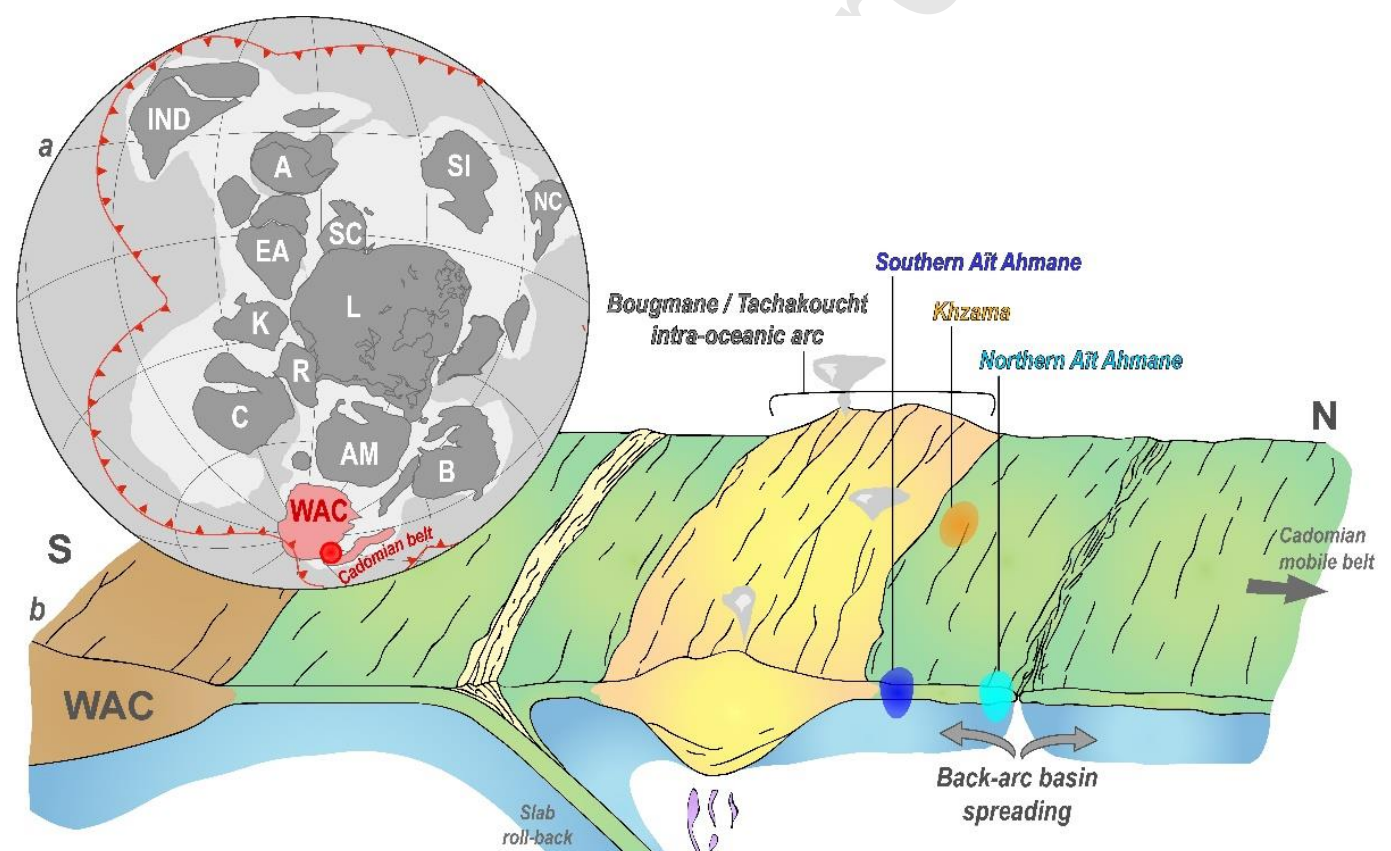

ca. $760 \mathrm{Ma}$

Figure 16: (a) Earth's paleogeography ca. 780 Ma, while Rodinia initiates its break-up (after Li et al., 2008). The WAC and the associated Cadomian mobile belt southward were located near the South Pole. Red dot represents the approximate location of the Anti-Atlasic subduction zone. Abbreviations are for: IND: India; A: Australia; SI: Siberia; NC: North China; SC: South China; EA: East Antarctica; L: Laurentia; K: Kalahari; R: Rio de la Plata; C: Congo; AM: Amazonia; B: Baltica; WAC: West African Craton. (b) Schematic geodynamic model that we propose for the Anti-Atlas ophiolites genesis, i.e. an intra-oceanic back-arc basin. Khzama and Southern Ait Ahmane units being more affected by SSZ-melts percolations and being closer to arc remnants, they likely originate from an earlier stage of the back-arc domain development compared to the North Aït Ahmane unit. 


\section{Acknowledgments}

The authors thank O. Bruguier, C. Douchet and L. Causse for their assistance on the ICP-MS and P. De Parseval and M. P. Castro for their assistance on electron microprobes. Authors are also grateful to the Microscopy and Microanalysis Laboratory (LMic) of the Universidade Federal de Ouro Preto, a member of the Microscopy and Microanalysis Network of Minas Gerais State/Brazil/FAPEMIG. U-Pb data on zircon were acquired in the GeOHeLiS analytical platform, Rennes University. This work has been funded by Research Grant 2016/06114-6 of the TelluS-SYSTER program of Institut national des sciences de l'Univers (INSU, CNRS, France) and French Ministère de l'Éducation nationale, de l'Enseignement supérieur et de la Recherche (MENESR). A.T. thanks the Rotary Club de Mons and the University of Mons for providing their financial support via the Pierre Jacobs post-doctoral grant (2018). AT is an FRS-FNRS post-doctoral research fellow for the PROBARC project (Grant CR n 1 . B. 414.20F). M.N.D. acknowledges support from US National Science Foundation grant EAR 1725002 and the Romanian Executive Agency for Higher Education, Research, Development and Innovation Funding project PN-III-P4-ID-PCCF-2016-0014. The authors are also grateful to Prof. A. Hassan and an anonymous reviewer for their careful reading and suggestions, which significantly improved this contribution. F.H. and A.T. are both first authors and contributed equally to this work.

\section{Data availability}

All data used in this manuscript are available in Supplementary materials 1-9. Further queries and information requests should be directed to the lead authors F.H. (florent.hodel@hotmail.fr) and A.T. (antoinetri@ gmail.com). 


\section{Bibliography}

Admou, H., Juteau, T., 1998. Discovery of a fossil oceanic hydrothermal system in the Late Precambrian Khzama ophiolite (Siroua massif, Anti-Atlas range, Morocco). Comptes Rendus l’Academie des Sci. Ser. IIA Earth Planet. Sci. 5, 335-340.

Admou, H., Razin, P., Egal, E., Youbi, N., Soulaimani, A., Blein, O., Chevremont, P., Gasquet, D., Barbanson, L., Bouabdelli, M., Anzar, C., 2013. Notice explicative de la Carte géologiques du Maroc (1/50 000), feuille Aït Ahmane. Notes Mémoires du Serv. Géologique du Maroc carte.

Ahmed, A.H., Arai, S., Ikenne, M., 2009. Mineralogy and Paragenesis of the Co-Ni Arsenide Ores of Bou Azzer, Anti-Atlas, Morocco. Econ. Geol. 104, 249-266. https://doi.org/10.2113/gsecongeo.104.2.249

Ahmed, H., Arai, S., Abdel-Aziz, Y.M., Rahimi, A., 2005. Spinel composition as a petrogenetic indicator of the mantle section in the Neoproterozoic Bou Azzer ophiolite, Anti-Atlas, Morocco. Precambrian Res. 138, 225-234. https://doi.org/10.1016/j.precamres.2005.05.004

Andreani, M., Escartin, J., Delacour, A., Ildefonse, B., Godard, M., Dyment, J., Fallick, A.E., Fouquet, Y., 2014. Tectonic structure, lithology, and hydrothermal signature of the Rainbow massif (MidAtlantic Ridge $\left.\quad 36^{\circ} 14^{\prime} \mathrm{N}\right)$. Geochemistry, Geophys. Geosystems 15, 3543-3571. https://doi.org/10.1002/2014GC005269

Arai, S., 1994. Compositional variation of olivine-chromian spinel in Mg-rich magmas as a guide to their residual spinel peridotites. J. Volcanol. Geotherm. Res. 59, 279-293. https://doi.org/10.1016/0377-0273(94)90083-3

Augustin, N., Paulick, H., Lackschewitz, K.S., Eisenhauer, A., Garbe-Schönberg, D., Kuhn, T., Botz, R., Schmidt, M., 2012. Alteration at the ultramafic-hosted Logatchev hydrothermal field: Constraints from trace element and Sr-O isotope data. Geochemistry, Geophys. Geosystems 13, n/a-n/a. https://doi.org/10.1029/2011GC003903 
Bach, W., Garrido, C.J., Paulick, H., Harvey, J., Rosner, M., 2004. Seawater-peridotite interactions: First insights from ODP Leg 209, MAR 15N. Geochemistry, Geophys. Geosystems 5, n/a-n/a. https://doi.org/10.1029/2004GC000744

Barrat, J.A., Zanda, B., Moynier, F., Bollinger, C., Liorzou, C., Bayon, G., 2012. Geochemistry of CI chondrites: Major and trace elements, and $\mathrm{Cu}$ and $\mathrm{Zn}$ Isotopes. Geochim. Cosmochim. Acta 83, 79-92. https://doi.org/10.1016/j.gca.2011.12.011

Barth, M.G., Mason, P.R.D., Davies, G.R., Drury, M.R., 2008. The Othris Ophiolite, Greece: A snapshot of subduction initiation at a mid-ocean ridge. Lithos 100, 234-254. https://doi.org/10.1016/J.LITHOS.2007.06.018

Beccaluva, L., Coltorti, M., Giunta, G., Siena, F., 2004. Tethyan vs. Cordilleran ophiolites: a reappraisal of distinctive tectono-magmatic features of supra-subduction complexes in relation to the subduction mode. Tectonophysics 393, 163-174. https://doi.org/10.1016/J.TECTO.2004.07.034

Bézos, A., Escrig, S., Langmuir, C.H., Michael, P.J., Asimow, P.D., 2009. Origins of chemical diversity of back-arc basin basalts: A segment-scale study of the Eastern Lau Spreading Center. J. Geophys. Res. 114, B06212. https://doi.org/10.1029/2008JB005924

Bizimis, M., Salters, V.J.M., Bonatti, E., 2000. Trace and REE content of clinopyroxenes from suprasubduction zone peridotites. Implications for melting and enrichment processes in island arcs. Chem. Geol. 165, 67-85. https://doi.org/10.1016/S0009-2541(99)00164-3

Blein, O., Baudin, T., Chevremont, P., Soulaimani, A., Admou, H., Gasquet, P.A., Cocherie, E., Egal, N., Youbi, f, P., Razin, P., 2014. Geochronological constraints on the polycyclic magmatism in the Bou Azzer-El Graara inlier (Central Anti-Atlas Morocco). J. African Earth Sci. 99, 287-306. https://doi.org/10.1016/J.JAFREARSCI.2014.04.021

Bodinier, J.-L., Godard, M., 2003. Orogenic, Ophiolitic, and Abyssal Peridotites, in: Treatise on Geochemistry. Elsevier, pp. 1-73. https://doi.org/10.1016/B0-08-043751-6/02004-1 
Bodinier, J.L., Dupuy, C., Dostal, J., 1984. Geochemistry of Precambrian ophiolites from Bou Azzer, Morocco. Contrib. to Mineral. Petrol. 87, 43-50. https://doi.org/10.1007/BF00371401

Boschi, C., Bonatti, E., Ligi, M., Brunelli, D., Cipriani, A., Dallai, L., D’Orazio, M., Früh-Green, G.L., Tonarini, S., Barnes, J.D., Bedini, R.M., 2013. Serpentinization of mantle peridotites along an uplifted lithospheric section, Mid Atlantic Ridge at $11^{\circ}$ N. Lithos 178, 3-23. https://doi.org/10.1016/j.lithos.2013.06.003

Bousquet, R., El Mamoun, R., Saddiqi, O., Goffé, B., Möller, A., Madi, A., 2008. Mélanges and ophiolites during the Pan-African orogeny: the case of the Bou-Azzer ophiolite suite (Morocco). Geol. Soc. London, Spec. Publ. 297, 233-247. https://doi.org/10.1144/SP297.11

Casey, J.F., 1997. Comparison of major and trace element geochemistry of abyssal peridotites and mafic plutonic rocks with basalts from the mark region of the Mid-Atlantic Ridge. Proc. Ocean Drill. Program, Sci. Results 153.

Chabane, A., 1991. Les roches vertes du Protérozoïque Supérieur de Khzama (Siroua, AntiAtlas, Maroc). Un exemple d'ophiolite d'avant arc formé en contexte de faille transformante. Université Cadi Ayyad, Marrakech, Maroc.

Chamberlain, K.R., Bowring, S.A., 2001. Apatite-feldspar U-Pb thermochronometer: a reliable, midrange $\quad\left(\sim 450^{\circ} \mathrm{C}\right), \quad$ diffusion-controlled system. Chem. Geol. 172, 173-200. https://doi.org/10.1016/S0009-2541(00)00242-4

Chen, L., Chu, F.-Y., Zhu, J.-H., Dong, Y.-H., Yu, X., Li, Z.-G., Tang, L.-M., 2015. Major and trace elements of abyssal peridotites: evidence for melt refertilization beneath the ultraslow-spreading Southwest Indian Ridge $\left(53^{\circ}\right.$ E segment). Int. Geol. Rev. 57, 1715-1734. https://doi.org/10.1080/00206814.2015.1029014

Cherniak, D.., Lanford, W.., Ryerson, F.., 1991. Lead diffusion in apatite and zircon using ion implantation and Rutherford Backscattering techniques. Geochim. Cosmochim. Acta 55, 1663-1673. https://doi.org/10.1016/0016-7037(91)90137-T 
Clauer, N., 1976. Géochimie isotopique du Strontium des milieux sédimentaires. Application à la géochronologie de la couverture du Craton Ouest-Africain. Strasbourg.

Cochrane, R., Spikings, R.A., Chew, D., Wotzlaw, J.-F., Chiaradia, M., Tyrrell, S., Schaltegger, U., Van der Lelij, R., 2014. High temperature $\left(\& \mathrm{gt} ; 350^{\circ} \mathrm{C}\right)$ thermochronology and mechanisms of $\mathrm{Pb}$ loss in apatite. Geochim. Cosmochim. Acta 127, 39-56. https://doi.org/10.1016/j.gca.2013.11.028

Coleman, R.G., Keith, T.E., 1971. A Chemical Study of Serpentinization--Burro Mountain, California. J. Petrol. 12, 311-328. https://doi.org/10.1093/petrology/12.2.311

Corfu, F., Hanchar, J.M., Hoskin, P.W.O., Kinny, P., 2003. Atlas of Zircon Textures. Rev. Mineral. Geochemistry 53, 469-500. https://doi.org/10.2113/0530469

Craddock, P.R., Bach, W., Seewald, J.S., Rouxel, O.J., Reeves, E., Tivey, M.K., 2010. Rare earth element abundances in hydrothermal fluids from the Manus Basin, Papua New Guinea: Indicators of sub-seafloor hydrothermal processes in back-arc basins. Geochim. Cosmochim. Acta 74, 5494-5513. https://doi.org/10.1016/j.gca.2010.07.003

D 'lemos, R.S., Inglis, J.D., Samson, S.D., 2006. A newly discovered orogenic event in Morocco: Neoproterozic ages for supposed Eburnean basement of the Bou Azzer inlier, Anti-Atlas Mountains. Precambrian Res. 147, 65-78. https://doi.org/10.1016/j.precamres.2006.02.003

Deschamps, F., Godard, M., Guillot, S., Hattori, K., 2013. Geochemistry of subduction zone serpentinites: A review. Lithos 178, 96-127. https://doi.org/10.1016/j.lithos.2013.05.019

Dick, H.J.B., Bullen, T., 1984. Chromian spinel as a petrogenetic indicator in abyssal and alpine-type peridotites and spatially associated lavas. Contrib. to Mineral. Petrol. 86, 54-76. https://doi.org/10.1007/BF00373711

Dilek, Y., and Furnes, H., 2011, Ophiolite genesis and global tectonics: Geochemical and tectonic fingerprinting of ancient oceanic lithosphere: Geological Society of America Bulletin, v. 123, p. 387-411, doi: 10.1130/B30446.1. 
Dubois-Cote, V., Hebert, R., Dupuis, C., Wang, C., Li, Y., Dostal, J., 2005. Petrological and geochemical evidence for the origin of the Yarlung Zangbo ophiolites, southern Tibet. Chem. Geol. 214, 265-286. https://doi.org/10.1016/J.CHEMGEO.2004.10.004

Eiler, J.M., Crawford, A., Elliott, T., Farley, K.A., Valley, J.W., Stolper, E.M., 2000. Oxygen Isotope Geochemistry of Oceanic-Arc Lavas. J. Petrol. 41, 229-256.

Eiler, J.M., Schiano, P., Valley, J.W., Kita, N.T., Stolper, E.M., 2007. Oxygen-isotope and trace element constraints on the origins of silica-rich melts in the subarc mantle. Geochemistry, Geophys. Geosystems 8.

El Boukhari, A., Chabane, A., Rocci, G., Tnae, J.L., 1992. Upper Proterozoic ophiolites of the Siroua Massif (Anti-Atlas, Morocco) a marginal sea and transform fault system. J. African Earth Sci. 14, 6780.

El Hadi, H., Simancas, J.F., Martínez-Poyatos, D., Azor, A., Tahiri, A., Montero, P., Fanning, C.M., Bea, F., González-Lodeiro, F., 2010. Structural and geochronological constraints on the evolution of the Bou Azzer Neoproterozoic ophiolite (Anti-Atlas, Morocco). Precambrian Res. 182, 1-14. https://doi.org/10.1016/j.precamres.2010.06.011

Furnes, H., Dilek, Y., de Wit, M., 2015. Precambrian greenstone sequences represent different ophiolite types. Gondwana Res. 27, 649-685. https://doi.org/10.1016/j.gr.2013.06.004

Gahlan, H.A., Arai, S., Ahmed, A.H., Ishida, Y., Abdel-Aziz, Y.M., Rahimi, A., 2006. Origin of magnetite veins in serpentinite from the Late Proterozoic Bou-Azzer ophiolite, Anti-Atlas, Morocco: An implication for mobility of iron during serpentinization. J. African Earth Sci. 46, 318-330. https://doi.org/10.1016/j.jafrearsci.2006.06.003

Gasquet, D., Ennih, N., Liégeois, J.-P., Soulaimani, A., Michard, A., 2008. The Pan-African Belt, in: Continental Evolution: The Geology of Morocco. Springer Berlin Heidelberg, Berlin, Heidelberg, pp. 33-64. https://doi.org/10.1007/978-3-540-77076-3_2 
Gasquet, D., Levresse, G., Cheilletz, A., Azizi-Samir, M.R., Mouttaqi, A., 2005. Contribution to a geodynamic reconstruction of the Anti-Atlas (Morocco) during Pan-African times with the emphasis on inversion tectonics and metallogenic activity at the Precambrian-Cambrian transition. Precambrian Res. 140, 157-182. https://doi.org/10.1016/j.precamres.2005.06.009

Godard, M., Bodinier, J.-L., Vasseur, G., 1995. Effects of mineralogical reactions on trace element redistributions in mantle rocks during percolation processes: A chromatographic approach. Earth Planet. Sci. Lett. 133, 449-461. https://doi.org/10.1016/0012-821X(95)00104-K

Godard, M., Jousselin, D., Bodinier, J.-L., 2000. Relationships between geochemistry and structure beneath a palaeo-spreading centre: a study of the mantle section in the Oman ophiolite. Earth Planet. Sci. Lett. 180, 133-148.

Godard, M., Lagabrielle, Y., Alard, O., Harvey, J., 2008. Geochemistry of the highly depleted peridotites drilled at ODP Sites 1272 and 1274 (Fifteen-Twenty Fracture Zone, Mid-Atlantic Ridge): Implications for mantle dynamics beneath a slow spreading ridge, Earth and Planetary Science Letters. https://doi.org/10.1016/j.eps1.2007.11.058

Gruau, G., Bernard-Griffiths, J., Lécuyer, C., 1998. The origin of U-shaped rare earth patterns in ophiolite peridotites: assessing the role of secondary alteration and melt/rock reaction. Geochim. Cosmochim. Acta 62, 3545-3560.

Hao, Y.-T., Xia, Q.-K., Tian, Z.-Z., Liu, J., Hao, Y.-T., Xia, Q.-K., Tian, Z.-Z., Liu, J., 2016. Mantle metasomatism did not modify the initial $\mathrm{H} 2 \mathrm{O}$ content in peridotite xenoliths from the Tianchang basalts of eastern China. Lithos 260, 315-327. https://doi.org/10.1016/j.lithos.2016.06.003

Hart, S.R., Zindler, A., 1986. In search of a bulk-Earth composition. Chem. Geol. 57, 247-267. https://doi.org/10.1016/0009-2541(86)90053-7

Harvey, J., Savov, I.P., Agostini, S., Cliff, R.A., Walshaw, R., 2014. Si-metasomatism in serpentinized peridotite: The effects of talc-alteration on strontium and boron isotopes in abyssal serpentinites from Hole 1268a, ODP Leg 209. Geochim. Cosmochim. Acta 126, 30-48. https://doi.org/10.1016/j.gca.2013.10.035 
Hefferan, K., Soulaimani, A., Samson, S.D., Admou, H., Inglis, J., Saquaque, A., Heywood, N., 2014. A reconsideration of Pan African orogenic cycle in the Anti-Atlas Mountains, Morocco. J. African Earth Sci. 98, 34-46. https://doi.org/10.1016/J.JAFREARSCI.2014.03.007

Heuret, A., Lallemand, S., 2005. Plate motions, slab dynamics and back-arc deformation. Phys. Earth Planet. Inter. 149, 31-51. https://doi.org/10.1016/J.PEPI.2004.08.022

Hickey-Vargas, R., Yogodzinski, G.M., Ishizuka, O., McCarthy, A., Bizimis, M., Kusano, Y., Savov, I.P., Arculus, R., 2018. Origin of depleted basalts during subduction initiation and early development of the Izu-Bonin-Mariana island arc: Evidence from IODP expedition 351 site U1438, AmamiSankaku basin. Geochim. Cosmochim. Acta 229, 85-111. https://doi.org/10.1016/J.GCA.2018.03.007

Hochstaedter, A., Gill, J., Peters, R., Broughton, P., Holden, P., Taylor, B., 2001. Across-arc geochemical trends in the Izu-Bonin arc: Contributions from the subducting slab. Geochemistry, Geophys. Geosystems 2, n/a-n/a. https://doi.org/10.1029/2000GC000105

Hodel, F., Macouin, M., Triantafyllou, A., Carlut, J., Berger, J., Rousse, S., Ennih, N., Trindade, R.I.F., 2017. Unusual massive magnetite veins and highly altered $\mathrm{Cr}$-spinels as relics of a Cl-rich acidic hydrothermal event in Neoproterozoic serpentinites (Bou Azzer ophiolite, Anti-Atlas, Morocco). Precambrian Res. 300, 151-167. https://doi.org/10.1016/j.precamres.2017.08.005

Hodel, F., Macouin, M., Trindade, R.I.F., Triantafyllou, A., Ganne, J., Chavagnac, V., Berger, J., Rospabé, M., Destrigneville, C., Carlut, J., Ennih, N., Agrinier, P., 2018. Fossil black smoker yields oxygen isotopic composition of Neoproterozoic seawater. Nat. Commun. https://doi.org/10.1038/s41467-018-03890-w

Hoskin, P.W.O., Schaltegger, U., 2003. The Composition of Zircon and Igneous and Metamorphic Petrogenesis. Rev. Mineral. Geochemistry 53, 27-62. https://doi.org/10.2113/0530027

Inglis, J.D., MacLean, J.S., Samson, S.D., D’Lemos, R.S., Admou, H., Hefferan, K., 2004. A precise $\mathrm{U}-\mathrm{Pb}$ zircon age for the Bleïda granodiorite, Anti-Atlas, Morocco: implications for the timing of deformation and terrane assembly in the eastern Anti-Atlas. J. African Earth Sci. 39, 277-283. https://doi.org/10.1016/J.JAFREARSCI.2004.07.041 
Ishii, T., Robinson, P.T., Maekawa, H., Fiske, R., 1992. Petrological Studies of Peridotites from Diapiric Serpentinite Seamounts in the Izu-Ogasawara-Mariana Forearc, Leg 125, in: Proceedings of the Ocean Drilling Program, 125 Scientific Results. Ocean Drilling Program, pp. 445-486. https://doi.org/10.2973/odp.proc.sr.125.129.1992

Iyer, K., Austrheim, H., John, T., Jamtveit, B., 2008. Serpentinization of the oceanic lithosphere and some geochemical consequences: Constraints from the Leka Ophiolite Complex, Norway. Chem. Geol. 249, 66-90. https://doi.org/10.1016/j.chemgeo.2007.12.005

Jagoutz, E., Palme, H., Baddenhausen, H., Blum, K., Cendales, M., Dreibus, G., Spettel, B., Lorenz, V., Wänke, H., 1979. The abundance of major, minor and trace elements in the Earth's mantle as derived from primitive ultramafic nodules. Proc. Lunar Planet. Sci. Conf. 10th 2031-2050.

Janecky, D.R., Seyfried, W.E., 1986. Hydrothermal serpentinization of peridotite within the oceanic crust: Experimental investigations of mineralogy and major element chemistry. Geochim. Cosmochim. Acta 50, 1357-1378. https://doi.org/10.1016/0016-7037(86)90311-X

Kelemen, P.B., Koga, K., Shimizu, N., 1997. Geochemistry of gabbro sills in the crust-mantle transition zone of the Oman ophiolite: implications for the origin of the oceanic lower crust. Earth Planet. Sci. Lett. 146, 475-488. https://doi.org/10.1016/S0012-821X(96)00235-X

Kodolányi, J., Pettke, T., Spandler, C., Kamber, B.S., Gméling, K., 2012. Geochemistry of Ocean Floor and Fore-arc Serpentinites: Constraints on the Ultramafic Input to Subduction Zones. J. Petrol. 53, 235-270. https://doi.org/10.1093/petrology/egr058

Kogiso, T., Tatsumi, Y., Nakano, S., 1997. Trace element transport during dehydration processes in the subducted oceanic crust: 1. Experiments and implications for the origin of ocean island basalts. Earth Planet. Sci. Lett.

Kydonakis, K., Kostopoulos, D., Poujol, M., Brun, J.P., Papanikolaou, D., Paquette, J.L., 2014. The dispersal of the Gondwana Super-fan System in the eastern Mediterranean: New insights from detrital zircon geochronology. Gondwana Res. 25, 1230-1241. https://doi.org/10.1016/j.gr.2013.05.009 
Leblanc, M., 1981. Chapter 17 The Late Proterozoic Ophiolites of Bou Azzer (Morocco): Evidence for Pan-African Plate Tectonics. Dev. Precambrian Geol. 4, 435-451. https://doi.org/10.1016/S01662635(08)70022-7

Leblanc, M., 1975. Ophiolites précambriennes et gites arséniés de Cobalt (Bou Azzer - Maroc). Université Paris VI, Paris.

Leake, B.E., Woolley, A.R., Birch, W.D., Burke, E.A.J., Ferraris, G., Grice, J.D., Hawthorne, F.C., Kisch, H.J., Krivovichev, V.G., Schumacher, J.C., Stephenson, N.C.N., Whittaker, E.J.W., 2004. Nomenclature of amphiboles: Additions and revisions to the International Mineralogical Association's amphibole nomenclature. Am. Mineral. 89, 883-887. https://doi.org/10.1180/0026461046810182

Li, Z.X., Bogdanov, S.V., Collins, A.S., Davidson, A., De Waele, B., Ernst, R.E., Fitzsimons, I.C.W., Fuck, R.A., Gladkochub, D.P., Jacobs, J., Karlstrom, K.E., Lu, S., Natapov, L.M., Pease, V., Pisarevsky, S.A., Thrane, K., Vernikovsky, V., 2008. Assembly, configuration, and break-up history of Rodinia: a synthesis. Precambrian Research 160, 179-210.

MacLeod, C.J., Johan Lissenberg, C., Bibby, L.E., 2013. "Moist MORB" axial magmatism in the Oman ophiolite: The evidence against a mid-ocean ridge origin. Geology 41, 459-462. https://doi.org/10.1130/G33904.1

Malvoisin, B., 2015. Mass transfer in the oceanic lithosphere: Serpentinization is not isochemical. Earth Planet. Sci. Lett. 430, 75-85. https://doi.org/10.1016/j.eps1.2015.07.043

Marchesi, C., Garrido, C.J., Godard, M., Belley, F., Ferré, E., 2009. Migration and accumulation of ultra-depleted subduction-related melts in the Massif du Sud ophiolite (New Caledonia). Chem. Geol. 266, 171-186. https://doi.org/10.1016/j.chemgeo.2009.06.004

Marchesi, C., Garrido, C.J., Godard, M., Proenza, J.A., Gervilla, F., Blanco-Moreno, J., 2006. Petrogenesis of highly depleted peridotites and gabbroic rocks from the Mayarí-Baracoa Ophiolitic Belt (eastern Cuba). Contrib. to Mineral. Petrol. 151, 717-736. https://doi.org/10.1007/s00410-0060089-0 
McDonough, W.F., Sun, S. -s., 1995. The composition of the Earth. Chem. Geol. 120, 223-253. https://doi.org/10.1016/0009-2541(94)00140-4

Miyashiro, A., Shido, F., Ewing, M., 1969. Composition and origin of serpentinites from the MidAtlantic Ridge near $24^{\circ}$ and $30^{\circ}$ North Latitude. Contrib. to Mineral. Petrol. 23, 117-127. https://doi.org/10.1007/BF00375173

Müller, R.D., Sdrolias, M., Gaina, C., Roest, W.R., 2008. Age, spreading rates, and spreading asymmetry of the world's ocean crust. Geochemistry, Geophys. Geosystems 9, n/a-n/a. https://doi.org/10.1029/2007GC001743

Naidoo, D.D., Bloomer, S.H., Saquaque, A., Hefferan, K., 1991. Geochemistry and significance of metavolcanic rocks from the Bou Azzer-El Graara ophiolite (Morocco). Precambrian Res. 53, 79-97.

Navon, O., Stolper, E., 1987. Geochemical Consequences of Melt Percolation: The Upper Mantle as a Chromatographic Column. J. Geol. 95, 285-307. https://doi.org/10.1086/629131

Niu, Y., 2004. Bulk-rock Major and Trace Element Compositions of Abyssal Peridotites: Implications for Mantle Melting, Melt Extraction and Post-melting Processes Beneath Mid-Ocean Ridges. J. Petrol. 45. https://doi.org/10.1093/petrology/egh068

Palandri, J.L., Reed, M.H., 2004. Geochemical models of metasomatism in ultramafic systems: serpentinization, rodingitization, and sea floor carbonate chimney precipitation. Geochim. Cosmochim. Acta 68, 1115-1133. https://doi.org/10.1016/j.gca.2003.08.006

Pallister, J.S., Knight, R.J., 1981. Rare-earth element geochemistry of the Samail Ophiolite near Ibra, Oman. J. Geophys. Res. Solid Earth 86, 2673-2697. https://doi.org/10.1029/JB086iB04p02673

Parkinson, I.J., Pearce, J.A., 1998. Peridotites from the Izu-Bonin-Mariana Forearc (ODP Leg 125): Evidence for Mantle Melting and Melt-Mantle Interaction in a Supra-Subduction Zone Setting. J. Petrol. 39, 1577-1618. https://doi.org/10.1093/petroj/39.9.1577

Paulick, H., Bach, W., Godard, M., De Hoog, J.C.M., Suhr, G., Harvey, J., 2006. Geochemistry of abyssal peridotites (Mid-Atlantic Ridge, $15^{\circ} 20^{\prime} \mathrm{N}$, ODP Leg 209): Implications for fluid/rock 
interaction in slow spreading environments. Chem. Geol. 234, 179-210. https://doi.org/10.1016/j.chemgeo.2006.04.011

Pearce, J.A., 2008. Geochemical fingerprinting of oceanic basalts with applications to ophiolite classification and the search for Archean oceanic crust. Lithos 100, 14-48. https://doi.org/10.1016/J.LITHOS.2007.06.016

Pearce, J.A., Barker, P.F., Edwards, S.J., Parkinson, I.J., Leat, P.T., 2000. Geochemistry and tectonic significance of peridotites from the South Sandwich arc-basin system, South Atlantic. Contrib. to Mineral. Petrol. 139, 36-53. https://doi.org/10.1007/s004100050572

Pearce, J.A., Lippard, S.J., Roberts, S., 1984. Characteristics and tectonic significance of suprasubduction zone ophiolites. Geol. Soc. London, Spec. Publ. 16.

Pearce, J.A., Stern, R.J., 2006. Origin of back-arc basin magmas: Trace element and isotope perspectives. American Geophysical Union, pp. 63-86. https://doi.org/10.1029/166GM06

Pearce, J.A., Stern, R.J., Bloomer, S.H., Fryer, P., 2005. Geochemical mapping of the Mariana arcbasin system: Implications for the nature and distribution of subduction components. Geochemistry, Geophys. Geosystems 6, n/a-n/a. https://doi.org/10.1029/2004GC000895

Prinzhofer, A., Allègre, C.J., 1985. Residual peridotites and the mechanisms of partial melting. Earth Planet. Sci. Lett. 74, 251-265. https://doi.org/10.1016/0012-821X(85)90025-1

Reagan, M.K., Ishizuka, O., Stern, R.J., Kelley, K.A., Ohara, Y., Blichert-Toft, J., Bloomer, S.H., Cash, J., Fryer, P., Hanan, B.B., Hickey-Vargas, R., Ishii, T., Kimura, J.-I., Peate, D.W., Rowe, M.C., Woods, M., 2010. Fore-arc basalts and subduction initiation in the Izu-Bonin-Mariana system. Geochemistry, Geophys. Geosystems 11, n/a-n/a. https://doi.org/10.1029/2009GC002871

Reagan, M.K., Pearce, J.A., Petronotis, K., Almeev, R.R., Avery, A.J., Carvallo, C., Chapman, T., Christeson, G.L., Ferré, E.C., Godard, M., Heaton, D.E., Kirchenbaur, M., Kurz, W., Kutterolf, S., Li, H., Li, Y., Michibayashi, K., Morgan, S., Nelson, W.R., Prytulak, J., Python, M., Robertson, A.H.F., Ryan, J.G., Sager, W.W., Sakuyama, T., Shervais, J.W., Shimizu, K., Whattam, S.A., 2017. 
Subduction initiation and ophiolite crust: new insights from IODP drilling. Int. Geol. Rev. 59, 14391450. https://doi.org/10.1080/00206814.2016.1276482

Saka, S., Uysal, I., Akmaz, R.M., Kaliwoda, M., Hochleitner, R., Saka, S., Uysal, I., Akmaz, R.M., Kaliwoda, M., Hochleitner, R., 2014. The effects of partial melting, melt-mantle interaction and fractionation on ophiolite generation: Constraints from the late Cretaceous Pozant1-Karsantı ophiolite, southern Turkey. Lithos 202-203, 300-316. https://doi.org/10.1016/j.lithos.2014.05.027

Samson, S.D., Inglis, J.D., D’Lemos, R.S., Admou, H., Blichert-Toft, J., Hefferan, K., 2004. Geochronological, geochemical, and $\mathrm{Nd}-\mathrm{Hf}$ isotopic constraints on the origin of Neoproterozoic plagiogranites in the Tasriwine ophiolite, Anti-Atlas orogen, Morocco. Precambrian Res. 135, 133147. https://doi.org/10.1016/j.precamres.2004.08.003

Saquaque, A., Admou, H., Karson, J., Hefferan, K., Reuber, I., 1989. Precambrian accretionary tectonics in the Bou Azzer-El Graara region, Anti-Atlas, Morocco. Geology 17, 1107. https://doi.org/10.1130/0091-7613(1989)017<1107:PATITB>2.3.CO;2

Savov, I.P., Ryan, J.G., D’Antonio, M., Fryer, P., 2007. Shallow slab fluid release across and along the Mariana arc-basin system: Insights from geochemistry of serpentinized peridotites from the Mariana fore arc. J. Geophys. Res. 112, B09205. https://doi.org/10.1029/2006JB004749

Savov, I.P., Ryan, J.G., D’Antonio, M., Kelley, K., Mattie, P., 2005. Geochemistry of serpentinized peridotites from the Mariana Forearc Conical Seamount, ODP Leg 125: Implications for the elemental recycling at subduction zones. Geochemistry, Geophys. Geosystems 6, n/a-n/a. https://doi.org/10.1029/2004GC000777

Schoene, B., Bowring, S.A., 2007. Determining accurate temperature-time paths from U-Pb thermochronology: An example from the Kaapvaal craton, southern Africa. Geochim. Cosmochim. Acta 71, 165-185. https://doi.org/10.1016/J.GCA.2006.08.029

Shinjo, R., Chung, S.-L., Kato, Y., Kimura, M., 1999. Geochemical and Sr-Nd isotopic characteristics of volcanic rocks from the Okinawa Trough and Ryukyu Arc: Implications for the evolution of a 
young, intracontinental back arc basin. J. Geophys. Res. Solid Earth 104, 10591-10608. https://doi.org/10.1029/1999JB900040

Snow, J.E., Dick, H.J.B., 1995. Pervasive magnesium loss by marine weathering of peridotite. Geochim. Cosmochim. Acta 59, 4219-4235. https://doi.org/10.1016/0016-7037(95)00239-V

Soulaimani, A., Jaffal, M., Maacha, L., Kchikach, A., Najine, A., Saidi, A., 2006. Modélisation magnétique de la suture ophiolitique de Bou Azzer-El Graara (Anti-Atlas central, Maroc). Implications sur la reconstitution géodynamique panafricaine. Comptes Rendus Geosci. 338, 153-160.

Soulaimani, A., Ouanaimi, H., Baidder, L., 2018. The Anti-Atlas Pan-African Belt (Morocco): Overview and pending questions. Comptes Rendus Geosci. 350, 279-288. https://doi.org/10.1016/J.CRTE.2018.07.002

Stern, R.J., 2005. Evidence from ophiolites, blueschists, and ultrahigh-pressure metamorphic terranes that the modern episode of subduction tectonics began in Neoproterozoic time. Geology 33, 557. https://doi.org/10.1130/G21365.1

Stern, R.J., Reagan, M., Ishizuka, O., Ohara, Y., Whattam, S., 2012. To understand subduction initiation, study forearc crust: To understand forearc crust, study ophiolites. Lithosphere 4, 469-483. https://doi.org/10.1130/L183.1

Sun, S. -s., McDonough, W.F., 1989. Chemical and isotopic systematics of oceanic basalts: implications for mantle composition and processes. Geol. Soc. London, Spec. Publ. 42.

Taylor, B., Martinez, F., 2003. Back-arc basin basalt systematics. Earth Planet. Sci. Lett. 210, 481497. https://doi.org/10.1016/S0012-821X(03)00167-5

Thomas, R.J., Chevallier, L.P., Gresse, P.G., Harmer, R.E., Eglington, B.M., Armstrong, R.A., de Beer, C.H., Martini, J.E.J., de Kock, G.S., Macey, P.H., Ingram, B.A., 2002. Precambrian evolution of the Sirwa Window, Anti-Atlas Orogen, Morocco. Precambrian Res. 118, 1-57. https://doi.org/10.1016/S0301-9268(02)00075-X 
Tian, L., Castillo, P.R., Hawkins, J.W., Hilton, D.R., Hanan, B.B., Pietruszka, A.J., 2008. Major and trace element and $\mathrm{Sr}-\mathrm{Nd}$ isotope signatures of lavas from the Central Lau Basin: Implications for the nature and influence of subduction components in the back-arc mantle. J. Volcanol. Geotherm. Res. 178, 657-670. https://doi.org/10.1016/j.jvolgeores.2008.06.039

Tollstrup, D., Gill, J., Kent, A., Prinkey, D., Williams, R., Tamura, Y., Ishizuka, O., 2010. Across- arc geochemical trends in the Izu- Bonin arc: Contributions from the subducting slab, revisited. Geochemistry, Geophys. Geosystems 11. https://doi.org/10.1029/2009GC002847@10.1002/(ISSN)1525-2027.IZUBONIN1

Triantafyllou A., Berger J., Diot H., Ennih N., Plissart G., 2012. Panafrican obduction, crushing \& shearing of the Neoproterozoic Khzama ophiolite (Anti-Atlas, Morocco). in 4th International Geologica Belgica Meeting, 11-14 sept, Brussels, Belgium.

Triantafyllou, A., Berger, J., Baele, J.-M., Bruguier, O., Diot, H., Ennih, N., Monnier, C., Plissart, G., Vandycke, S., Watlet, A., 2018. Intra-oceanic arc growth driven by magmatic and tectonic processes recorded in the Neoproterozoic Bougmane arc complex (Anti-Atlas, Morocco). Precambrian Res. 304, 39-63. https://doi.org/10.1016/j.precamres.2017.10.022

Triantafyllou, A., Berger, J., Baele, J.-M., Diot, H., Ennih, N., Plissart, G., Monnier, C., Watlet, A., Bruguier, O., Spagna, P., Vandycke, S., 2016. The Tachakoucht-Iriri-Tourtit arc complex (Moroccan Anti-Atlas): Neoproterozoic records of polyphased subduction-accretion dynamics during the PanAfrican orogeny. J. Geodyn. 96, 81-103. https://doi.org/10.1016/j.jog.2015.07.004

Triantafyllou, A., Watlet, A., Bastin, C., 2017. Geolokit: An interactive tool for visualising and exploring geoscientific data in Google Earth. Int. J. Appl. Earth Obs. Geoinf. 62, 39-46. https://doi.org/10.1016/j.jag.2017.05.011

Triantafyllou, A., Berger, J., Baele, J. M., Mattielli, N., Ducea, M. N., Sterckx, S., \& Ennih, N. (2020). Episodic magmatism during the growth of a Neoproterozoic oceanic arc (Anti-Atlas, Morocco). Precambrian Research, 339, 105610. 
Ulrich, M., Picard, C., Guillot, S., Chauvel, C., Cluzel, D., Meffre, S., 2010. Multiple melting stages and refertilization as indicators for ridge to subduction formation: The New Caledonia ophiolite. Lithos 115, 223-236. https://doi.org/10.1016/j.lithos.2009.12.011

Uysal, I., Ersoy, E.Y., Dilek, Y., Kapsiotis, A., Sarıfakığlu, E., 2016. Multiple episodes of partial melting, depletion, metasomatism and enrichment processes recorded in the heterogeneous upper mantle sequence of the Neotethyan Eldivan ophiolite, Turkey. Lithos 246, 228-245. https://doi.org/10.1016/j.lithos.2016.01.004

Uysal, I., Ersoy, E.Y., Dilek, Y., Escayola, M., Sarıfakıoğlu, E., Saka, S., Hirata, T., 2015. Depletion and refertilization of the Tethyan oceanic upper mantle as revealed by the early Jurassic Refahiye ophiolite, NE Anatolia-Turkey. Gondwana Res. 27, 594-611. https://doi.org/10.1016/j.gr.2013.09.008

Uysal, İ., Ersoy, E.Y., Karslı, O., Dilek, Y., Sadıklar, M.B., Ottley, C.J., Tiepolo, M., Meisel, T., 2012. Coexistence of abyssal and ultra-depleted SSZ type mantle peridotites in a Neo-Tethyan Ophiolite in SW Turkey: Constraints from mineral composition, whole-rock geochemistry (major-trace-REEPGE), and Re-Os isotope systematics. Lithos 132, 50-69. https://doi.org/10.1016/j.lithos.2011.11.009 Vermeesch, P., 2018. IsoplotR: A free and open toolbox for geochronology. Geosci. Front. 9, 14791493. https://doi.org/10.1016/J.GSF.2018.04.001

Vernières, J., Godard, M., Bodinier, J.-L., 1997. A plate model for the simulation of trace element fractionation during partial melting and magma transport in the Earth's upper mantle. J. Geophys. Res. Solid Earth 102, 24771-24784. https://doi.org/10.1029/97JB01946

Walsh, G.J., Benziane, F., Aleinikoff, J.N., Harrison, R.W., Yazidi, A., Burton, W.C., Quick, J.E., Saadane, A., 2012. Neoproterozoic tectonic evolution of the Jebel Saghro and Bou Azzer-El Graara inliers, eastern and central Anti-Atlas, Morocco. Precambrian Res. 216, 23-62. https://doi.org/10.1016/j.precamres.2012.06.010

Warren, J.M., 2016. Global variations in abyssal peridotite compositions. Lithos 248-251, 193-219. https://doi.org/10.1016/j.lithos.2015.12.023 
Warren, J.M., Shimizu, N., 2010. Cryptic Variations in Abyssal Peridotite Compositions: Evidence for Shallow-level Melt Infiltration in the Oceanic Lithosphere. J. Petrol. 51, 395-423. https://doi.org/10.1093/petrology/egp096

Winchester, J.A., Floyd, P.A., 1977. Geochemical discrimination of different magma series and their differentiation products using immobile elements. Chem. Geol. 20, 325-343. https://doi.org/10.1016/0009-2541(77)90057-2

Woelki, D., Regelous, M., Haase, K.M., Romer, R.H.W., Beier, C., 2018. Petrogenesis of boninitic lavas from the Troodos Ophiolite, and comparison with Izu-Bonin-Mariana fore-arc crust. Earth Planet. Sci. Lett. 498, 203-214. https://doi.org/10.1016/j.eps1.2018.06.041

Workman, R.K., Hart, S.R., 2005. Major and trace element composition of the depleted MORB mantle (DMM). Earth Planet. Sci. Lett. 231, 53-72. https://doi.org/10.1016/j.epsl.2004.12.005

You, C., Castillo, P., Gieskes, J., Chan, L., 1996. Trace element behavior in hydrothermal experiments: implications for fluid processes at shallow depths in subduction zones. Earth Planet.

Zou, H., 2007. Quantitative geochemistry. Imperial College Press. 


\section{Declaration of interests}

$\bigotimes$ The authors declare that they have no known competing financial interests or personal

relationships that could have appeared to influence the work reported in this paper.

$\square$ The authors declare the following financial interests/personal relationships which may be considered as potential competing interests: 


\section{CRediT author statement}

Florent Hodel : Conceptualization, Investigation, Writing - Original Draft, Visualization; Antoine Triantafyllou: Conceptualization, Investigation, Funding acquisition, Writing - Original Draft, Visualization; Julien Berger: Investigation, Writing - Review \& Editing; Mélina Macouin : Investigation, Supervision, Funding acquisition, Writing - Review \& Editing; Jean-Marc Baele : Investigation, Writing - Review \& Editing; Nadine Mattielli : Supervision, Writing - Review \& Editing; Christophe Monnier : Investigation, Supervision, Writing - Review \& Editing; Ricardo Ivan Ferreira da Trindade : Supervision, Funding acquisition, Writing - Review \& Editing; Mihai Ducea : Supervision, Writing - Review \& Editing; Adil Chatir : Investigation, Writing - Review \& Editing; Nasser Ennih : Investigation, Supervision, Writing - Review \& Editing; Jessica Langlade : Formal analysis, Validation; Marc Poujol : Methodology, Formal analysis, Validation, Writing - Review \& Editing 
Graphical abstract
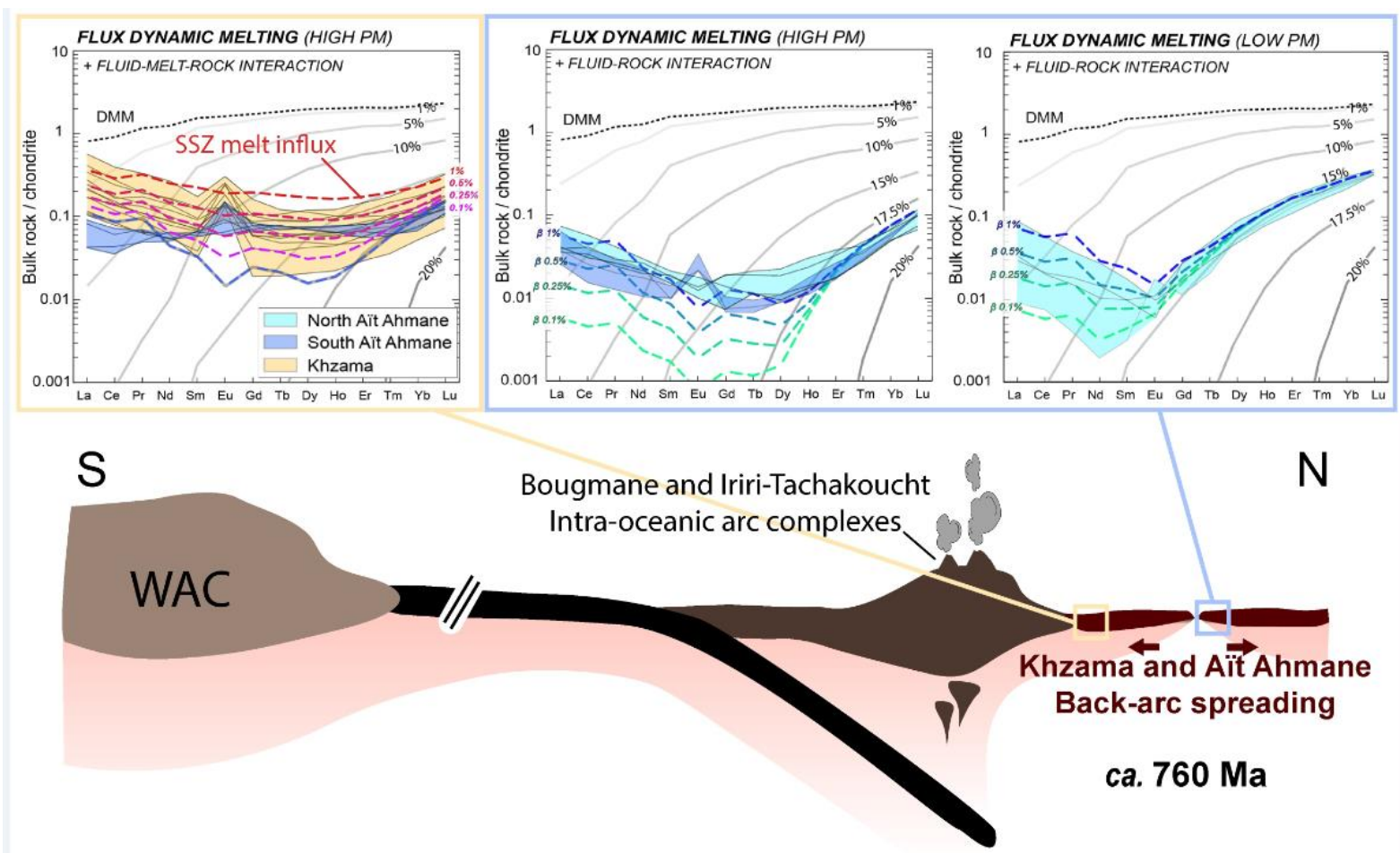

Khzama and A $\overrightarrow{i t}$ Ahmane

Back-arc spreading

ca. $760 \mathrm{Ma}$ 


\section{Highlights}

- Magmatic age of the Bou Azzer ophiolite (Moroccan Anti-Atlas) is $759 \pm 2 \mathrm{Ma}$

- Sirwa and Bou Azzer ophiolites originate from a same intra-oceanic back-arc system

- Both ophiolites recorded multiple arc-back-arc evolution stages 